\title{
The petrogenesis of sodic island arc magmas at Savo volcano, Solomon Islands
}

\section{Authors}

\author{
D. J. Smith ${ }^{\text {a, }}$, M. G. Petterson ${ }^{\text {a, b }}$, A. D. Saunders ${ }^{\text {a }}$, I. L. Millar ${ }^{c}$, G. R. T. Jenkin ${ }^{\text {a }}$, T. Toba ${ }^{\text {d }}$, J. Naden ${ }^{\text {b }}$, \\ J. M. Cook ${ }^{b}$ \\ ${ }^{a}$ Department of Geology, University of Leicester, LE1 7RH, UK \\ ${ }^{\mathrm{b}}$ British Geological Survey, Keyworth, Nottingham, NG12 5GG, UK \\ ${ }^{c}$ NERC Isotope Geosciences Laboratory, Kingsley Dunham Centre, Keyworth, Nottingham NG12 5GG, \\ UK \\ ${ }^{\mathrm{d}}$ Ministry of Energy Water and Mineral Resources, Honiara, Solomon Islands \\ * Corresponding author. Tel.: +44 (0)116 252 3315. Fax: +44 (0)116 252 3918. Email: djs40@le.ac.uk
}

\begin{abstract}
Savo, Solomon Islands, is a historically active volcano dominated by sodic, alkaline lavas and pyroclastic rocks with up to $7.5 \mathrm{wt} \% \mathrm{Na}_{2} \mathrm{O}$, and high $\mathrm{Sr}$, arc-like trace element chemistry. The suite is dominated by mugearites (plagioclase-clinopyroxene-magnetite \pm amphibole \pm olivine) and trachytes (plagioclaseamphibole-magnetite \pm biotite). The presence of hydrous minerals (amphibole, biotite) indicates relatively wet magmas. In such melts, plagioclase is relatively unstable relative to iron oxides and ferromagnesian silicates; it is the latter minerals (particularly hornblende) that dominate cumulate nodules at Savo and drive the chemical differentiation of the suite, with a limited role for plagioclase. This is potentially occurring in a crustal "hot zone”, with major chemical differentiation occurring at depth. Batches of magma ascend periodically, where they are subject to decompression, water saturation and further cooling, resulting in closed-system crystallisation of plagioclase, and ultimately the production of sodic, crystal and feldspar-rich, high-Sr rocks. The sodic and hydrous nature of the parental magmas is interpreted to be the result of partial melting of metasomatised mantle, but radiogenic isotope data $(\mathrm{Pb}, \mathrm{Sr}, \mathrm{Nd})$ cannot uniquely identify the source of the metasomatic agent.
\end{abstract}

\section{Keywords}

Sodic, island arc, trachyte, mugearite, alkaline, Solomon Islands, Savo, hot zone

\section{Introduction}

The Solomon Islands arc has experienced a complex subduction history, involving the collision of an oceanic large igneous province (the Ontong Java Plateau; Hughes 2004; Petterson et al. 1997), initiation of a second subduction zone (Petterson et al. 1999), and the subduction of a young oceanic spreading ridge (Crook and Taylor 1994). These process have contributed to a number of unusual magmatic features, including volcanism on the plate being subducted (Simbo; König et al. 2007) and in the forearc region (Kavachi; Johnson and Tuni 1987); picritic magmas (Schuth et al. 2004); high magnesian andesites and adakites (König et al. 2007); and alkaline magmas (DeLong et al. 1975). 
Savo occupies an ambiguous tectonic position, approximately equidistant between the two opposing subduction zones that define the arc (Fig. 1). The volcano is constructed on unknown basement. Fresh magmatic rocks at Savo display a number of unusual characteristics, including high sodium contents (up to 7.5 wt \% $\mathrm{Na}_{2} \mathrm{O}$ ), increasing Sr with fractionation, and abundant ultramafic nodules. Along with Kavachi, Savo is one of only two historically active volcanoes in the arc. The role that the various tectonic elements and events have played in magma genesis at Savo remains unclear. Previous authors have related the magmatism at Savo to the subduction zone to the south (Petterson et al. 2003) but a relationship to the northern subduction zone has not been ruled out (Cooper and Taylor 1987). There is scope for interaction between both subduction zones in magmatic processes in the Solomon Islands. Previous studies have provided brief summaries of chemistry and petrology at Savo (Petterson et al. 2003; Stanton 1994). Here we provide a critical assessment of petrogenesis at Savo, important for understanding tectonic and large-scale chemical processes of the Solomon Islands in particular, and the southwest Pacific in general.

\section{Tectonic and geological history of the Solomon Islands}

The Solomon Islands were formed by the ongoing convergence of the Indo-Australian and Pacific plates (Fig. 1). Southward subduction of the Pacific plate at the North Solomon Trench System (NSTS) commenced in the Eocene (Petterson et al. 1999). Sometime before 6.4 Ma, the Ontong Java Plateau (an Alaska-sized oceanic large igneous province) “choked” the NSTS resulting in initiation of subduction of the Indo-Australian Plate at the South Solomon Trench System (SSTS; Cooper and Taylor 1987; Petterson et al. 1999; Phinney et al. 2004). Intermittent subduction along the NSTS still occurs (Auzende et al. 1996; Cooper and Taylor 1987; Kroenke 1995). The subducted Pacific slab may still be a source of metasomatic fluids and melts to the sub-arc mantle (e.g. König et al. 2007).

Subduction of the Indo-Australian Plate at the SSTS continues at the present day. Earthquake hypocentres show that the Indo-Australian slab dips vertically to $250 \mathrm{~km}$ in the western region of the arc and vertically to $100 \mathrm{~km}$ in the eastern end of the arc (Cooper and Taylor 1987). However, in the central Solomon Islands seismicity is low magnitude, shallow and diffuse. The poor definition of the slab by seismic studies is thought to be a result of the relative warmth of the young lithosphere of the Woodlark Basin (and its subducted equivalent) compared to older, colder lithosphere to the east and west (Cooper and Taylor 1987; Mann et al. 1998).

Subduction of the Woodlark Basin is considered to be a major influence on structure and magmatism in the Solomon Islands (Cooper and Taylor 1987; Johnson et al. 1987; Taylor and Exon 1987). Spreading at the Woodlark Ridge began before 5 Ma (based on magnetic lineations; Taylor 1987) and ceased at approximately 0.5 Ma (Crook and Taylor 1994). One of the Woodlark Ridge transform faults intersects the SSTS to produce a trench-trench-transform triple junction east of Simbo Island (Crook and Taylor 1994). The combined divergence and subduction of the Woodlark Ridge is believed to have led to the formation of "windows" in the IndoAustralian slab beneath the arc (Chadwick et al. 2009; Johnson et al. 1987; Perfit et al. 1987; Taylor 1987; Taylor and Exon 1987). The development of slab windows is believed to be responsible for fore-arc magmatism at Kavachi (Johnson et al. 1987), and the genesis of island arc picrites in New Georgia (Johnson et al. 1987; Perfit et al. 1987; Rohrbach et al. 2003; Schuth et al. 2004). 
Savo volcano

Savo volcano is $35 \mathrm{~km}$ northwest of Honiara, the administrative capital of the Solomon Islands (98`S $\left.159^{\circ} 49^{`} \mathrm{E}\right)$. The volcano has a basal diameter of $9 \mathrm{~km}$ and a height of approximately $1400 \mathrm{~m}$, and is constructed on 14 km thick oceanic crust (Furumoto et al. 1976; Petterson et al. 2003). The upper portion of the volcano is above sea level - Savo Island is approximately $7 \mathrm{~km}$ long $(\mathrm{N}-\mathrm{S})$ by $6 \mathrm{~km}$ wide $(\mathrm{E}-\mathrm{W})$, with a high point of $485 \mathrm{~m}$. The centre of the island is marked by a $1.5 \mathrm{~km}$ wide, approximately $80 \mathrm{~m}$ deep crater. At least two heavily vegetated, small lava domes are visible in the central crater, along with a number of steeper domes in the south and southwest of the island. Streams drain from the outer crater wall in a radial pattern, dissecting the island into a series of steep-sided gorges and valleys. A number of streams originate at inland hot springs. With the exception of the steep domes in the southwest of the island, pyroclastic and reworked pyroclastic deposits are ubiquitous on the island, and include block and ash flow (BAF), debris flow, tephra fall, lahar, and surge deposits (Petterson et al. 2003). Coherent lavas (and/or intrusive bodies) are limited to the domes in the crater and southwest of the island, and discontinuous, heavily weathered exposures in valleys (Savo map in supplementary data).

\section{Sampling and analytical methods}

Due to intense tropical weathering, in-situ outcrops were rarely suitable for analytical work. Fresh samples were collected from volcaniclastic deposits, stream-cut exposures, beaches, and wherever possible, from exposed coherent lavas. Sample location map is in the electronic supplement. A number of samples were nodules within a larger body of host rock, and some of the samples collected as individual blocks (particularly the most mafic) may represent nodules separated from the host rock during transport.

Weathered surfaces were removed from samples by splitter or rock saw prior to crushing. Samples were crushed to coarse chips using a hardened steel press and rendered to a powder in an agate planetary mill at the University of Leicester, with the exception of samples for Pb isotope ratio determination which were milled to a find powder in tungsten carbide, rather than agate.

Whole rock major and trace element compositions were analysed with a Philips PW1400 (samples SV165) or PANalytical PW4400 Axios Advanced (samples SV151-400) X-ray fluorescence spectrometer at the University of Leicester, using standard methods (Smith 2008). A range of reference materials (RMs) were used to calibrate both instruments. The precision $(1 \sigma)$ of the major element data, across a range of compositions, was estimated to be $<3 \%$ for $\mathrm{SiO}_{2}, \mathrm{Al}_{2} \mathrm{O}_{3}, \mathrm{Fe}_{2} \mathrm{O}_{3}, \mathrm{MgO}, \mathrm{CaO}$ and $\mathrm{Na}_{2} \mathrm{O},<7 \%$ for $\mathrm{TiO}_{2}$ and $\mathrm{MnO},<10 \%$ for $\mathrm{K}_{2} \mathrm{O}$ and $\mathrm{P}_{2} \mathrm{O}_{5}$. For trace elements at concentrations above10 ppm the precision was $<15 \%$ for $\mathrm{Ba}$; $<10 \%$ for Ce, Co, Cr, $\mathrm{Cu}, \mathrm{Ni}, \mathrm{Sc}$; and $<5 \%$ for Ga, Rb, Sr, V, Zn, Zr. For trace elements at concentrations below $10 \mathrm{ppm}$, the estimated for precision were $<1$ ppm for $\mathrm{Ga}, \mathrm{Nb}, \mathrm{Rb}$; $<2$ ppm for $\mathrm{Co}, \mathrm{Cu}, \mathrm{La}, \mathrm{Nd}, \mathrm{Ni}, \mathrm{Y}$; $<4$ ppm for $\mathrm{Ba}, \mathrm{Cr}, \mathrm{Th}$, Zr. Measured values for RMs were within $1 \sigma$ of accepted values. There was no significant difference between results from the two spectrometers.

Rare earth elements were analysed by solution ICP-MS at the British Geological Survey Keyworth, following sodium peroxide fusion of powdered samples (Smith 2008). Accuracy was estimated from analysis of certified RMs and was typically within $10 \%$ of the accepted values. Precision $(1 \sigma)$ was estimated to be $<0.05$ ppm for Ho, Lu, Pr, Tb, Tm; <0.1 ppm for Eu, Pr; <0.2 ppm for Dy, Er, Sm, Yb; <1 ppm for Ce, Gd, La, Nd. 
Mineral chemistry data were collected using a JEOL 8600 Superprobe at the University of Leicester (Smith 2008). Precision for electron probe analysis was calculated from counting statistics, and was generally better than $\pm 1 \%$ for measurements $>10 \mathrm{wt} \%$, and better than $\pm 5 \%$ for contents $>0.5 \mathrm{wt} \%$. Microprobe data tables are in the Supplementary Data.

Strontium and neodymium isotope ratio determinations were carried out at the NERC Isotope Geosciences Laboratory (NIGL). Strontium and neodymium fractions were prepared using standard techniques outlined in Royse et al. (1998). Samples were analysed using a Thermo-Finnigan Triton thermal ionisation mass spectrometer. The Sr blank at the time of analysis was 111 pg. Replicate analyses of the SRM987 standard solution gave an average value of $0.710263 \pm 4(1 \sigma, n=50)$. Data are reported normalised to SRM987= 0.710250. A number of samples were leached in $\mathrm{HCl}$ to ascertain the effect of minor alteration; no significant difference in ${ }^{87} \mathrm{Sr} /{ }^{86} \mathrm{Sr}$ was found between leached and unleached sample fractions. The Nd blank at the time of analysis was $132 \mathrm{pg}$. Replicate analyses of the J\&M standard solution gave an average value of $0.511104 \pm$ $0.000012(2 \sigma, \mathrm{n}=50)$. Data are reported normalised to J\&M solution standard $=0.511123$.

Samples for the determination of $\mathrm{Pb}$ isotope ratios were prepared using techniques described by Kempton and McGill (2002). Pb isotope ratios were determined at NIGL using a VG Axiom, MC-ICP-MS instrument for samples spiked with $\mathrm{Tl}$. All Pb isotope ratios have been corrected relative to the NBS 981 composition of Thirlwall (2002). Blanks are typically less than 200 pg, although one high blank (2 ng) was obtained during the time of analysis.

\section{Results}

Samples from Savo are divided into two groups: the main suite consists of crystal rich trachytes, mugearites and occasional benmoreites, defined on the basis of total alkalis versus silica (Fig. 2), and by virtue of their sodic chemistry $\left(\mathrm{Na}_{2} \mathrm{O}-2>\mathrm{K}_{2} \mathrm{O}\right)$. Nodules commonly occur as inclusions within main suite samples. The nodules include a wide variety of mineralogies, and occur in range of sizes, from $30 \mathrm{~cm}$ in diameter, to xenocrysts and micro-nodules identifiable only at thin section scale.

Petrography and mineral chemistry - main suite

The main suite of samples are typically crystal-rich (55-70\% crystals by volume) and porphyritic with hyalopilitic groundmass (Fig. 3a), although a small number of the mafic (hawaiite and mugearite) samples collected from small exposures of lava flow deposits are entirely crystalline, with phenocrysts of clinopyroxene and olivine $(0.5-3 \mathrm{~mm})$ in a groundmass of plagioclase crystals $(0.3-3 \mathrm{~mm}$; Fig. 3b).

Plagioclase and magnetite occur in all samples. There is a progressive change in the mafic mineral assemblage with increasing whole rock $\mathrm{SiO}_{2}$, from clinopyroxene mugearites to clinopyroxene-amphibole mugearites, amphibole benmoreites and finally amphibole-biotite trachytes (Fig. 4). Olivine is present in a small number of the more mafic samples. Anhydrite was observed in one trachyte sample (SV40). Needle-like apatite crystals can be seen in trachytic samples. Apatite crystals are more readily distinguished as inclusions within feldspar phenocrysts due to the microlite-rich nature of the groundmass.

Plagioclase is ubiquitous throughout the suite, and constitutes $25-35 \%$ of the sample volume of mugearites, and 40-45\% of benmoreites and trachytes (Fig. 4). Crystals are typically euhedral laths in thin section at $<0.2 \mathrm{~mm}$ to over $10 \mathrm{~mm}$ in rare cases, but more typically 2-3 mm. A significant quantity of fragmented crystals is also present. Normal zoning is common (Fig. 3a). Plagioclase crystals in mugearites 
range from $A n_{85}-\mathrm{An}_{50}$, often within a single crystal; in benmoreites the range is from $\mathrm{An}_{80}-\mathrm{An}_{30}$. Plagioclase within trachytes is commonly $\mathrm{An}_{40}-\mathrm{An}_{10}$, although some crystals are $\mathrm{An}_{75}-\mathrm{An}_{20}$. Potassium contents are low; rare outliers with $>5 \%$ orthoclase (Or) may be a result of minor alteration. Occasionally plagioclase contains inclusions of amphibole and magnetite.

Magnetite occurs throughout the suite as a minor phenocryst phase (1-12\% by volume; Fig. 4), with crystals typically $<0.3 \mathrm{~mm}$. Magnetite has been observed as inclusions within all major phenocryst phases. Many magnetite crystals show well developed exsolution lamellae under reflected light. Electron microprobe analysis of magnetite frequently returned analyses with totals $<90 \mathrm{wt} \%$, with iron analysed as FeO (the ideal total for pure magnetite is 93\%). This may be a result of an excess of the $\mathrm{Fe}_{2} \mathrm{O}_{3}$ component, i.e. the magnetites are approaching the maghemite endmember. Magnetite-maghemite solid solution is probably a result of subsolidus oxidation (Haggerty 1976).

Clinopyroxene occurs in the hawaiites, mugearites and one benmoreite sample (SV12; Fig. 3c), typically as well developed phenocrysts between 0.5 and $2 \mathrm{~mm}$ diameter, up to $30 \%$ by volume (Fig. 4). Zoning, exsolution lamellae and reaction rims are rarely observed. Clinopyroxene crystals occasionally contain inclusions of magnetite (up to $0.3 \mathrm{~mm}$, typically well developed crystals), and rarely plagioclase $(<0.2 \mathrm{~mm}$, poorly developed crystals). Pyroxenes from the main suite fall in a narrow compositional range that spans the augite-diopside compositional boundary; they are typically aluminian and aluminian-ferrian diopsides/augites, with a smaller proportion ( $<10 \%$ of analyses) of chromian diopsides and augites. There is little covariation of pyroxene chemistry with whole rock chemistry.

Olivine occurs as phenocrysts (up to $2 \mathrm{~mm}$ diameter) in a small number of mugearitic samples, where it constitutes up to 7\% by volume (Fig. 4). Crystals are typically rounded with the margins altered to iddingsite. Microprobe analyses are available only for sample SV1; analysed crystals are $\mathrm{Fo}_{70-80}$, with Ca contents of $0.15-$ 0.20 wt \%.

Amphibole occurs over a wide range of whole rock $\mathrm{SiO}_{2}$ values (from 52 to 65 wt \%), and after plagioclase is the most abundant phenocryst mineral. Amphibole is commonly present as well developed crystals and laths, typically crystals are between 0.5 and $1 \mathrm{~mm}$ but occasionally over $3 \mathrm{~mm}$ in length. Amphibole shows strong pleochroism ( $\alpha=$ pale green, $\beta=$ pale green-yellow, $\gamma=$ deep green; or $\alpha=$ yellow, $\beta=$ reddish brown, $\gamma=$ brown). Zoning was observed in a number of well-formed crystals.

All fresh amphiboles are hornblende group (sensu lato), the majority being pargasites and magnesiohastingsites, with a smaller number of edenites and magnesiohornblendes. Significant variations in composition (e.g. Si, $\mathrm{Na}_{\mathrm{A}}+\mathrm{K}_{\mathrm{A}}$, Mg\#) occur within single samples, and even within single crystals. For example, a single crystal in SV40 was found to be normally (with minor oscillations) zoned from $\mathrm{Mg \#}(\mathrm{Mg} / \mathrm{Mg}+\mathrm{Fe}) 0.79$ to 0.55 , as $\mathrm{Na}_{\mathrm{A}}+\mathrm{K}_{\mathrm{A}}$ varied from 0.55 to 0.9 . No systematic variation in zoning was observed for the suite; normal, reverse and oscillatory zoning all occur, as do homogeneous crystals.

In a number of samples, hornblende displays opaque rims, and in some (including SV12, 20, 29) the amphibole is completely pseudomorphed by finely crystalline opaque minerals (Fig. 3c). Stanton (1994) found the replacing assemblage to be a mixture of clinopyroxene, magnetite and plagioclase with trace quartz and hematite, in his study of pseudomorphed and rimmed amphiboles from Guadalcanal and Savo.

Biotite occurs in benmoreite and trachyte samples, typically as small ( $<0.5 \mathrm{~mm})$ crystals; rare examples with diameters up to $2 \mathrm{~mm}$ were observed. Biotite is often deformed, and in rare examples may be seen as 
inclusions within large amphibole crystals. Biotite typically constitutes between 3 and 7\% by volume of samples with whole rock $\mathrm{SiO}_{2}>60$ wt \%. Biotites are relatively magnesium rich (Mg\# typically 0.6-0.7). The majority of samples analysed are part of the annite-phlogopite series (sensu Tischendorf et al. 2007), with a significant proportion sufficiently Mg-rich to be classified as phlogopite.

Petrography and mineral chemistry - nodules

Nodules are subdivided on the basis of dominant mineralogy:

Hornblendites (sensu lato) are composed of amphibole (>90\%) with minor clinopyroxene and magnetite \pm plagioclase \pm apatite. Amphibole crystals are typically $>2 \mathrm{~mm}$, and can measure up to $3 \mathrm{~cm}$. Texture varies according to mineralogy: plagioclase \pm apatite-bearing samples typically have euhedral amphibole crystals, with interstitial plagioclase and apatite; plagioclase-free and plagioclase-poor samples are much more common on Savo, and are dominated by anhedral amphibole. The samples are consistent with cumulate textures, with plagioclase-free orthocumulates (Fig. 3d) and plagioclase-bearing adcumulates (Fig. 3e). Amphibole compositions in nodules overlap with those from the main suite. Plagioclase in hornblendites may be more calcic than in the main suite (SV38, SV181 nodules are $\mathrm{An}_{80-90}$ ) but not in all cases (Fig. 5).

Clinopyroxenites are dominated by clinopyroxene, with olivine, minor amphibole, and magnetite, and display orthocumulate textures. Amphibole can be seen to be replacing clinopyroxene in a number of samples, especially at the contact between the host rock and the nodule, and also occurs as an intercumulus phase, typically leading to poikilitic textures. Clinopyroxene chemistries overlap with those of the main suite, tending to be slightly more Mg-rich. From the small number of olivine analyses there is no appreciable difference in Fo\% between the nodules and main suite, but the nodule olivines are less calcic than those of the main suite ( $>0.1$ versus $\sim 0.2$ wt \% CaO, respectively).

Hornblende gabbros are coarsely crystalline (1-5 mm) with plagioclase, amphibole, clinopyroxene and magnetite (Fig. 3f). Amphiboles are often blackened or partially replaced by clinopyroxene and magnetite. Hornblende gabbros are transitional between hornblendites and main suite hawaiites and mugearites in terms of mineralogy and texture.

Major element chemistry

Main suite samples from Savo are mildly alkaline and sodic $\left(\mathrm{Na}_{2} \mathrm{O}-2>\mathrm{K}_{2} \mathrm{O}\right)$, and are classed as mugearites, benmoreites and trachytes, with occasional hawaiites and dacites (Fig. 2; Table 1). The majority of analysed samples are silica saturated and metaluminous, but a small number of mugearites are nephelinenormative.

Major element trends for the main suite and nodules are shown in Harker variation diagrams in Fig. 6. Samples from the main suite show well defined linear relationships for all elements relative to $\mathrm{SiO}_{2}$. There is a paucity of benmoreites relative to the mugearites and trachytes; to what extent this reflects a sampling bias rather than a real lack of benmoreites in the erupted material at Savo is difficult to ascertain. Most major element oxides show relatively simple trends versus silica. The exceptions are $\mathrm{Al}_{2} \mathrm{O}_{3}$, which shows a weakly defined linear increase as $\mathrm{SiO}_{2}$ increases from 50-55 wt \% $\mathrm{SiO}_{2}$, and plateaus at approximately $18 \mathrm{wt} \%$ at higher $\mathrm{SiO}_{2}$ values. $\mathrm{P}_{2} \mathrm{O}_{5}$ is relatively constant at 0.18-0.26 for samples with low $\mathrm{SiO}_{2} ;$ at $\mathrm{SiO}_{2}>62$ wt \% phosphorous contents decrease steadily as silica increases. 
Major element trends for nodules are more scattered, due to the varied mineralogy and small sample populations. Clinopyroxenite samples (SV159 and SV161) show features - e.g. low Al; high Fe - that reflect the predominance of clinopyroxene, with increased olivine contents in SV159 leading to higher Mg contents (Table 2).

Hornblendites SV6A, 155 and 175 cluster closely on plots of all major element oxides, with the exception of $\mathrm{TiO}_{2}$ as it is controlled by magnetite, which is a variable minor phase. Notably, the hornblendites are colinear with main suite samples for the major elements except Al and P. Sample SV181 plots separately from the other hornblendites, with lower $\mathrm{SiO}_{2}(\sim 34$ wt \%) and Mg, and significantly higher Ti, Fe and P, which is consistent with increased magnetite and apatite contents.

Hornblende gabbro nodules are approximately co-linear with the main suite for the elements $\mathrm{Al}, \mathrm{Ca}, \mathrm{Na}$, $\mathrm{K}$ and Fe (Fig. 6). Magnesium contents are more varied, but as displayed by the hornblendites and clinopyroxenites, $\mathrm{Mg}$ is susceptible to variations in modal olivine and clinopyroxene.

Trace element chemistry

Trace element data (Tables 1 and 2) are shown as Harker variation diagrams (Fig. 7). For the most part, incompatible elements ( $\mathrm{Ba}, \mathrm{Zr}, \mathrm{Rb})$ increase and compatible elements (Co, Cr, $\mathrm{V}$ ) decrease with increasing $\mathrm{SiO}_{2}$. A notable feature of the suite is the increase in $\mathrm{Sr}$ content with $\mathrm{SiO}_{2}$. Strontium and barium show weakly bimodal distributions, with a cluster of mugearite and benmoreite samples at lower concentrations, and a trachyte cluster at higher contents.

For nodules, Ba, Rb, Sr and Zr are approximately co-linear with the main suite. The compatible elements show significant scatter for the nodules relative to the main suite; $\mathrm{Cr}$ in particular shows significant enrichment (relative to the overall trend) in the clinopyroxenites and clinopyroxene-bearing hornblendites (i.e. excluding SV181).

Rare earth element chemistry

All samples are enriched relative to average $\mathrm{C} 1$ chondrite (Tables 1 and 2; Fig. 8). As $\mathrm{SiO}_{2}$ increases, the REE profiles become steeper due to progressive depletion of the MREE and HREE. The change in slope of the REE profile can be expressed as the increase in $\mathrm{La}_{\mathrm{N}} / \mathrm{Yb}_{\mathrm{N}}$ and $\mathrm{La}_{\mathrm{N}} / \mathrm{Dy}_{\mathrm{N}}$ from 3-4 to 6-10 as $\mathrm{SiO}_{2}$ increases from 50-66 wt \%; over the same silica range, $\mathrm{Dy}_{\mathrm{N}} / \mathrm{Yb}_{\mathrm{N}}$ increases from 2 to 4 . Europium anomalies are absent in most samples, with only trachytes SV2, 17 and 39 showing weak positive anomalies $\left(\mathrm{Eu} / \mathrm{Eu}^{*}=1.2\right.$, based on the deviation from the geometric mean of $\mathrm{Sm}_{\mathrm{N}}$ and $\mathrm{Gd}_{\mathrm{N}}$ ).

The rare earth profiles for two hornblendites (SV181 and SV6A) are included in Fig. 8. The two differ in terms of LREE, with SV181 considerably more enriched in La-Nd compared to SV6A. This is assumed to be a result of high apatite content in SV181, also reflected in the high $\mathrm{P}_{2} \mathrm{O}_{5}$ content.

Radiogenic isotopes

In the main suite, ${ }^{87} \mathrm{Sr} /{ }^{86} \mathrm{Sr}$ ranges between 0.7040-0.7042 (Table 1; Fig. 9). Trachytes tend to dominate the upper end of this range, but overlap with mugearites, so there appears to be little significant variation in ${ }^{87} \mathrm{Sr} /{ }^{86} \mathrm{Sr}$ with composition. 
The lead isotope ratios show no resolvable variation with increasing whole-rock $\mathrm{SiO}_{2}$ (Table 1; Fig. 9), and are similar to volcanic samples from the western Solomon Islands (König et al. 2007). There is no observable variation of ${ }^{143} \mathrm{Nd} /{ }^{144} \mathrm{Nd}$ with increasing $\mathrm{SiO}_{2}$, with data clustered tightly around 0.51297 .

\section{Discussion}

The role of water in petrogenesis at Savo

A number of petrological and geochemical features point to high pre-eruptive water contents in the magmas at Savo. High concentrations of fluid-mobile elements ( $\mathrm{Sr}, \mathrm{Ba}, \mathrm{Rb}$ ) in mafic samples are consistent with melt generation from hydrated mantle (Pearce 1982), and the presence of amphibole and biotite requires high water contents (>3 wt \%) in the crystallising magmas (Barclay and Carmichael 2004; Gill 1981; Moore and Carmichael 1998; Sisson and Grove 1993). Pre-eruptive conditions (temperature, pressure, $\mathrm{pH}_{2} \mathrm{O}$ ) are difficult to determine precisely due to the mineralogy (e.g. one pyroxene, no ilmenite), lack of glass and widespread development of opaque-rich rims on amphiboles. However, numerous experiments have been undertaken on arc basalts and the qualitative aspects of those experiments should apply to Savo.

High water contents in basaltic melts have the effect of destabilising silicate minerals, plagioclase in particular (Gaetani et al. 1993; Gill 1981; Sisson and Grove 1993). Plagioclase is suppressed at high water contents, and occurs as a liquidus phase at lower temperatures and pressures in hydrous basalts than in anhydrous equivalents (Gaetani et al. 1993). Oxides are affected much less than silicates by high water contents. Thus, arc basalts typically fractionate assemblages (in order of appearance, rather than abundance) of magnetite $>$ olivine $>$ clinopyroxene $>$ plagioclase (Sisson and Grove 1993). High $\mathrm{fO}_{2}$ (the presence of anhydrite in SV40 indicates $\mathrm{fO}_{2} \geq \mathrm{NNO}+1$; Carroll and Rutherford, 1987) would also stabilise oxides relative to silicates.

Amphibole is stabilised as a liquidus phase at high water contents (>3 wt \%), particularly in sodic melts (Sisson and Grove 1993).

The presence of clinopyroxenite and in particular, hornblendite cumulates, at Savo is consistent with the fractionation of a hydrous magma. With reference to the mineralogy of the main suite, clinopyroxenites would be the dominant cumulate early in the fractionation, as clinopyroxene and olivine are the main mafic phases in the least evolved mugearites (Fig. 4). Hornblende does not appear until greater degrees of differentiation, and so the hornblendites are expected to represent a later fractionating assemblage. However, the role of plagioclase in the differentiation of the suite is unclear - the majority of cumulates are plagioclase-poor, and Sr behaves as an incompatible element with increasing differentiation (Fig. 7) indicating a limited role for plagioclase in fractionating assemblages.

Strontium data from main suite plagioclase crystals indicate further complexity. Fig. 10a shows that the plagioclase compositions can be divided into two groups within the main suite - mugearites and benmoreites (characterised by a relatively flat trend of $\mathrm{SrO}$ with decreasing $\mathrm{X}_{\mathrm{An}}$ ) and trachytes (sharply decreasing from high initial $\mathrm{SrO}$ with decreasing $\mathrm{X}_{\mathrm{An}}$ ). A small number of benmoreite-hosted crystals lie closer to the trachyte group (i.e. elevated $\mathrm{SrO}$ for a given $\mathrm{X}_{\mathrm{An}}$ ). Core-to-rim traverses did not locate any elevated SrO zones with crystals; rather, the entire crystal would be elevated relative to the predominant trend. Given these crystals occur within the same sections as “normal” plagioclase, they may represent xenocrysts or products of magma mingling. By 
comparison, $\mathrm{BaO}$ from the same analysed crystals does not show two distinct groupings - instead it shows one trend with increasing $\mathrm{BaO}$ with decreasing $\mathrm{X}_{\mathrm{An}}$ (Fig. 11).

Fig. 10b uses the equation of Blundy and Wood (1991) for $\mathrm{D}_{\mathrm{Sr}}$ varying with $\mathrm{X}_{\mathrm{An}}$ to calculate equilibrium melt Sr. Equilibrium melt compositions slope steeply down from high initial Sr ( 1000 ppm) as $\mathrm{X}_{\mathrm{An}}$ decreases, within both the mugearite/ benmoreite group and trachyte groups. Closed system crystallisation of plagioclase is the most obvious explanation of the trend within a group - plagioclase crystallises, progressively exhausting the melt of Sr. Plagioclase fractionation is limited, at least within the trachytes, as whole rock Sr is greater than any calculated melt composition. The whole rock chemistry of these crystal rich rocks does not reflect a liquid line of descent.

Fig. 10b shows that trachytes evolved from melts with higher Sr than mugearites and benmoreites. However, the $\mathrm{BaO}-\mathrm{X}_{\mathrm{An}}$ plot (Fig. 11) does not show two trends, and when considering that ${ }^{87} \mathrm{Sr} /{ }^{86} \mathrm{Sr}$ shows little difference between mugearitic and trachytic compositions, this would seem to rule out a significant role for assimilation. The whole rock chemistry, although not representing liquid lines of descent, does show linear trends for most elements, implying a common origin for mugearites and trachytes.

Hydrous arc magmas may fractionate and evolve according to the "hot zone” model of Annen et al. (2006), where parental magmas undergo significant amounts of differentiation in lower crustal intrusions, with periodic release of fractionated daughter magmas into shallow chambers. To apply this model to Savo, magnetite, clinopyroxene, amphibole and limited amounts of plagioclase (plus minor olivine and apatite) are fractionated extensively in deeper intrusions (and recovered as cumulate nodules), then evolved magmas ascend to shallow levels where plagioclase is "frozen in" by rapid crystallisation. The primary control on chemistry is the deep fractionation event, where linear trends in elements such as $\mathrm{Co}, \mathrm{V}, \mathrm{Ba}$, and $\mathrm{Zr}$ are generated for the main suite as they are either entirely compatible with the mafic mineral assemblages, or entirely incompatible (i.e. bulk D values remain above or below 1 regardless of the minerals fractionating). Strontium behaves as an incompatible element when plagioclase crystallisation is limited. Upon ascent, batches of magma are subject to decreasing pressure, decreasing water solubility, and ultimately water saturation and degassing. Plagioclase will begin crystallising, or will constitute an increasingly large proportion of the crystallising assemblage as the system moves to lower water contents, and Sr will behave compatibly and leave the melt fraction progressively depleted (as per Fig. 10b). Viscosity will increase, thus limiting plagioclase fractionation, and so crystal-rich, high-Sr mushes will be produced.

The role of the deep fractionation of mafic minerals, and in particular amphibole, has a number of important controls on geochemistry at Savo. Rare earth element profiles of the main suite exhibit curves characteristic of hornblende fractionation, with progressive MREE-HREE depletion (Fig. 8; compare with hornblendite SV6A). LREE remain relatively consistent, a result of apatite saturation and fractionation in the more evolved rocks (see $\mathrm{P}_{2} \mathrm{O}_{5}$-rich hornblendite SV181, Fig. 8). Hornblende fractionation (plus minor plagioclase removal in hornblende gabbro-type cumulates) also limits the progressive increase in whole rock $\mathrm{Al}_{2} \mathrm{O}_{3}$, preventing the melts from becoming corundum normative, and increases $\mathrm{SiO}_{2}$, moving compositions away from silica-undersaturated to saturated conditions (Martin 2007). Minimal plagioclase fractionation at Savo, and the dominance of calcic compositions in cumulates when it does occur (Fig. 5) serve to maintain the high sodium content of the whole rocks. Sodium is retained along with $\mathrm{Sr}$ in the feldspar, whereas in the case of plagioclase fractionation, the suite would become more potassic with differentiation. Potassium does indeed 
increase at Savo, but whole rock values remain sufficiently sodic that $\mathrm{Na}_{2} \mathrm{O}-2$ is greater than $\mathrm{K}_{2} \mathrm{O}$ throughout the main suite.

The trachytes of Savo show a number of geochemical characteristics in common with adakites (Defant and Drummond 1990). However, the geochemical criteria for defining a rock as adakitic are genetically nonunique (Richards and Kerrich 2007). Already the importance of amphibole fractionation has been demonstrated at Savo, and the late crystallisation and retention of plagioclase further emphasises the high $\mathrm{Sr} / \mathrm{Y}$ value of the magma. The most likely explanation for the "adakitic signatures” at Savo is that initially Sr-rich, hydrous arc basalt/ hawaiite fractionates an amphibole-dominated assemblage, resulting in increasing $\mathrm{La} / \mathrm{Yb}$, and $\mathrm{Sr} / \mathrm{Y}$.

The plagioclase crystal chemistry plots show a bimodal distribution within the main suite, with only a minority of crystals from benmoreite hosts displaying intermediate $\mathrm{SrO}-\mathrm{X}_{\mathrm{An}}$ compositions (Fig. 10). To what extent this gap is real or an artefact of sampling is unclear. Compositional gaps can develop by periodic extraction of fractionated liquids from magmas when a critical degree of crystallisation is reached (Brophy and Dreher 2000). By this mechanism, extraction of a trachytic liquid from crystallising mugearite at Savo would require release of the daughter liquid prior to significant plagioclase crystallisation (to maintain high Sr in the daughter). Alternatively, benmoreites at Savo might have a tendency to remain in the upper crust, rather than ascending to surface, perhaps as a result of neutral buoyancy, high viscosity or deeper water saturation (by virtue of higher water contents than mugearites through fractionation, and lower water solubility than trachytes by virtue of melt composition). Simply put, a wide compositional range of melts can be released from depth following fractionation from a parental melt, and all begin closed-system (plagioclase-dominated) crystallisation upon water saturation - the depth of water saturation will vary for the different melt compositions. Without data to constrain melt $\mathrm{H}_{2} \mathrm{O}$ contents at Savo, this hypothesis cannot presently be tested.

Sodic magmas at Savo

Sodic magmas (where $\mathrm{Na}_{2} \mathrm{O}-2>\mathrm{K}_{2} \mathrm{O}$ ) are unusual occurrences in arcs, although they may be generated by a number of mechanisms, including: partial melting of subducted slabs; partial melting of underplated basaltic crust (Atherton and Petford 1993); assimilation of basaltic lower crustal material (Feeley and Hacker 1995); partial melting of mantle metasomatised by aqueous fluids (Kamenov et al. 2008; McInnes and Cameron 1994) and/or melts from subducted slabs (Kepezhinskas et al. 1995); and small degrees of partial melting of the mantle in truncated melt columns (Hole and Saunders 1996).

Models involving extensive interaction with crustal material are unlikely at Savo. Radiogenic isotope data preclude the involvement of compositionally (or temporally) distinct material, and crustal thickness beneath Savo (approximately $14 \mathrm{~km}$; Petterson et al. 2003) is much thinner than in those models that involve extensive crustal interaction (Atherton and Petford 1993; Feeley and Hacker 1995).

DeLong et al. (1975) compiled data for sodic magmas in intra-oceanic arcs and observed that these rock types occur in a number of specific tectonic settings: 1) near lateral edges of subduction zones where hinge faulting is occurring (Bering, Fiji, Grenada) and 2) where fracture zones and ridges are being subducted at a high angle (Kanaga, Aoba and Ambrym, New Georgia, Iwo-jima). DeLong et al. (1975) suggested that the subduction of these linear features provides pathways for magmas from regions beneath or within the subducted lithosphere, an idea further expanded into a model of slab window development. Thorkelson and Breitsprecher (2005) predicted that melts above such a slab window would likely be adakitic, due to thermal erosion of the slab window margins during mantle upwelling. The slab window model is viable for the Solomon Arc, and 
explains a number of features in the western portion of the arc, including forearc volcanism (Johnson et al. 1987), island arc picrites (Schuth et al. 2004), and volcanism on the plate being subducted (Chadwick et al. 2009; König et al. 2007).

Slab melts and aqueous fluids from subducted slabs can enrich the mantle by metasomatism (Gregoire et al. 2001; Kepezhinskas et al. 1995; McInnes et al. 2001; Pearce and Peate 1995; Rapp et al. 1999). At low melt/rock ratios, slab melts enrich the mantle wedge with mobile elements, and particularly with $\mathrm{Na}$ (Kepezhinskas et al. 1995; Xiong et al. 2006), rather than ascending to the surface as pristine adakites or mantlehybridised high magnesian andesites (HMAs; Kepezhinskas et al. 1995; Rapp et al. 1999). Given the presence of HMAs in the western Solomon Islands (New Georgia Province and Simbo; König et al. 2007), as well as the favourable tectonic setting for partial melting of the subducted slab, this is an appealing agent for enriching mantle-derived melts with $\mathrm{Na}$ at Savo.

Enrichment of the mantle has occurred further west in the Tabar-Lihir-Tanga-Feni island arc of Papua New Guinea, where alkaline eruptive suites commonly contain mantle xenoliths that indicate widespread metasomatism beneath the arc (Gregoire et al. 2001; Kamenov et al. 2008; McInnes and Cameron 1994). Various interpretations have been made of the origin of the metasomatism in this region, including partial melting of subducted crust as the geotherms recover at the stalled slab, resulting in adakite genesis (Kamenov et al. 2008). However, other studies have concluded that the metasomatic agent was a hydrous fluid (Gregoire et al. 2001). Under high pressure and temperature conditions $\left(1250^{\circ} \mathrm{C}, 15-25 \mathrm{~kb}\right)$, aqueous fluids derived from a dehydrating slab are capable of carrying significant mass fractions of mobile elements. Under such conditions, aqueous fluids and silicate melts may be entirely miscible, and would have similar solvent properties (Ayers and Eggler 1995; Bureau and Keppler 1999). It therefore makes it difficult to discriminate between slab melt and hydrous metasomatism on the basis of trace and major elements alone. In fact, the presence of arc-like $\mathrm{Ba}$ and $\mathrm{Sr}$ enrichments in basalts erupted in the Woodlark Basin suggests that the Pacific slab has a "hydrous footprint" that extends a considerable distance south of the arc (Perfit et al. 1987; Woodhead et al. 1998).

The geographical location of Savo places it in an ambiguous position above both the Pacific and IndoAustralian slabs. Both slabs have the potential to dehydrate, or partially melt, given the unusual tectonic scenario (stalled subduction, young crust, and slab window development). Radiogenic isotopes do not clearly distinguish fluid/ melt sources at Savo, particularly if subducted sediments are involved (Fig. 9). Both processes could occur in tandem, given the two subducted slabs present beneath the arc, to give rise to alkali-enriched, metasomatised mantle and ultimately to sodic magmas at Savo.

\section{Conclusions}

The erupted material at Savo spans a broad range of compositions, from mafic to felsic, with abundant nodules of cognate ultramafic material. The trace element, isotopic and mineral chemistry of the samples analysed in this study indicate that the various compositions at Savo have a common origin, but have undergone distinct differentiation and crystallisation histories.

The fractionation models at Savo are consistent with "hot zone” models of arc magmatism (Annen et al. 2006), where primitive, hydrous mantle melts are emplaced at deep crustal levels, undergo high temperature and pressure differentiation by the fractionation of ferromagnesian silicates and oxides to establish major chemical variations. High water contents suppress plagioclase relative to mafic minerals. Evolved magmas 
ascend to shallower levels, where water saturation and further crystallisation occurs. At Savo, plagioclase crystallisation occurs as a closed-system process, resulting in strongly normal-zoned feldspars, and high wholerock strontium concentrations. Distinct feldspar crystallisation trends are visible within the suite, indicating that distinct batches of magma are released after relatively plagioclase poor fractionation at depth, to crystallise upon ascent. Limited plagioclase fractionation retains the sodic chemistry in terms of whole rock compositions.

The hydrous, sodic magmas that occur at Savo are most likely derived from a metasomatised mantle wedge. The metasomatic "footprint” of either the Pacific or Indo-Australian slabs extends a considerable distance away from the respective trenches, and Savo's location equidistant between the two slabs means that an unequivocal slab source cannot be identified. The unusual tectonic features of the Solomon Islands are important contributors to forearc volcanism and picrite petrogenesis elsewhere in the arc. This study of Savo volcano indicates that alkaline magmatism is another notable product of the complex geodynamic setting of the arc.

\section{Acknowledgements}

This research was funded by the Natural Environment Research Council (UK) and British Geological Survey University Funding Initiative as part of PhD studentship NER/S/A/2004/12339. Analytical work was supported by NERC Isotope Geosciences Facilities Steering Committee grant IP/889/1105. Additional fieldwork funds were provided by Society of Economic Geologists Student Research Grants (Hugh E. McKinstry Fund and Newmont Mining Corporation Grant). Thanks to KA Green (BGS) and A Sumner (NIGL) for assistance with analytical work; W Satokana, G Albert, A Ramo, D Billy and S Basi (Solomon Islands Ministry of Natural Resources), the British High Commission (Honiara) for assistance with fieldwork; D Selles (Harvard) for helpful discussion. We thank G Moore, editor TL Grove and an anonymous reviewer for comments which have greatly improved this manuscript. MGP, ILM, JN, and JMC publish with the permission of the Executive Director, British Geological Survey (NERC). 


\section{References}

Annen C, Blundy JD, Sparks RSJ (2006) The genesis of intermediate and silicic magmas in deep crustal hot zones. J Petrol 47(3):505-539

Atherton MP, Petford N (1993) Generation of sodium-rich magmas from newly underplated basaltic crust. Nature 362(6416):144-146

Auzende J-M, Kroenke LW, Collot JY, Lafoy Y, Pelletier B, Collot J-Y (1996) Compressive tectonism along the eastern margin of Malaita Island (Solomon Islands). Mar Geophys Res 18:289-304

Ayers JC, Eggler DH (1995) Partitioning of elements between silicate melt and $\mathrm{H}_{2} \mathrm{O}$ - $\mathrm{NaCl}$ fluids at 1.5 and 2.0 GPa pressure: Implications for mantle metasomatism. Geochim Cosmochim Acta 59(20):4237-4246

Barclay J, Carmichael ISE (2004) A hornblende basalt from western Mexico: Water-saturated phase relations constrain a pressure-temperature window of eruptibility. J Petrol 45(3):485-506

Blundy JD, Wood BJ (1991) Crystal-chemical controls on the partitioning of Sr and Ba between plagioclase feldspar, silicate melts, and hydrothermal solutions. Geochim Cosmochim Acta 55:193-209

Boynton WV (1984) Geochemistry of the rare earth elements: meteorite studies. In: Henderson P (ed) Rare Earth Element Geochemistry. Elsevier, pp 63-114

Brophy JG, Dreher ST (2000) The origin of composition gaps at South Sister volcano, central Oregon: implications for fractional crystallization processes beneath active calc-alkaline volcanoes. J Volcanol Geotherm Res 102(3-4):287-307

Bureau H, Keppler H (1999) Complete miscibility between silicate melts and hydrous fluids in the upper mantle: experimental evidence and geochemical implications. Earth Planet Sci Lett 165(2):187-196

Carroll MR, Rutherford MJ (1987) The stability of igneous anhydrite: experimental results and implications for sulfur behavior in the 1982 El Chichon trachyandesite and other evolved magmas. J Petrol 28(5):781-801

Chadwick J, Perfit M, McInnes B, Kamenov G, Plank T, Jonasson I, Chadwick C (2009) Arc lavas on both sides of a trench: Slab window effects at the Solomon Islands triple junction, SW Pacific. Earth Planet Sci Lett 279(3-4):293-302

Cooper P, Taylor B (1987) The spatial distribution of earthquakes, focal mechanisms and subducted lithosphere in the Solomon Islands. In: Taylor B, Exon NF (eds) Marine Geology, Geophysics and Geochemistry of the Woodlark Basin-Solomon Islands, vol 7. pp 67-80

Crook KAW, Taylor B (1994) Structure and Quaternary tectonic history of the Woodlark Triple Junction region, Solomon Islands. Mar Geophys Res 16(1):65-89

Defant M, Drummond MS (1990) Derivation of some modern arc magmas by melting of young subducted lithosphere. Nature 347(6294):662-665

DeLong SE, Hodges FN, Arculus R (1975) Ultramafic and mafic inclusions, Kanaga Island, Alaska, and the occurrence of alkaline rocks in island arcs. J Geol 83:721-736

Feeley TC, Hacker MD (1995) Intracrustal derivation of Na-rich andesitic and dacitic magmas - an example from Volcan Ollague, Andean Central Volcanic Zone. J Geol 103(2):213-225

Furumoto AS, Webb JP, Odegard ME, Hussong DM (1976) Seismic studies on the Ontong Java Plateau, 1970. Tectonophysics 34(1-2):71-90

Gaetani GA, Grove TL, Bryan WB (1993) The influence of water on the petrogenesis of subduction related igneous rocks. Nature 365(6444):332-334

Gill JB (1981) Orogenic Andesites and Plate Tectonics. Springer-Verlag, New York

Gregoire M, McInnes BIA, O'Reilly SY (2001) Hydrous metasomatism of oceanic sub-arc mantle, Lihir, Papua New Guinea - Part 2. Trace element characteristics of slab-derived fluids. Lithos 59(3):91-108

Haggerty SE (1976) Oxidation of opaque mineral oxides in basalts. In: Rumble III D (ed) Oxide Minerals, vol 3. Hofmann AW (1997) Mantle geochemistry: the message from oceanic volcanism. Nature 385(6613):219-229

Hole MJ, Saunders AD (1996) The generation of small melt-fractions in truncated melt columns: constraints from magmas erupted above slab windows and implications for MORB genesis. Mineral Mag 60:173-189 
Hughes GW (2004) Accretion of the Ontong Java Plateau to the Solomon arc: a historical perspective. Tectonophysics 389(3-4):127-136

Johnson RW, Jaques AL, Langmuir CH, Perfit MR, Staudigel H, Dunkley PN, Chappell BW, Taylor SR, Baekisapa M (1987) Ridge subduction and forearc volcanism; petrology and geochemistry of rocks dredged from the western Solomon Arc and Woodlark Basin. In: Taylor B, Exon NF (eds) Marine Geology, Geophysics and Geochemistry of the Woodlark Basin-Solomon Islands, vol 7. pp 155-226

Johnson RW, Tuni D (1987) Kavachi, an active forearc volcano in the western Solomon Islands: reported eruptions between 1950 and 1982. In: Taylor B, Exon NF (eds) Marine Geology, Geophysics and Geochemistry of the Woodlark Basin-Solomon Islands, vol 7. pp 89-112

Kamenov GD, Perfit MR, Mueller PA, Jonasson IR (2008) Controls on magmatism in an island arc environment: study of lavas and sub-arc xenoliths from the Tabar-Lihir-Tanga-Feni island chain, Papua New Guinea. Contrib Mineral Petrol 155(5):635-656

Kempton PD, McGill R (2002) Procedures for the analysis of common lead at the NERC Isotope Geosciences Laboratory and an assessment of data quality. In. NERC Isotope Geosciences Laboratory, p 59

Kepezhinskas PK, Defant MJ, Drummond MS (1995) Na metasomatism in the island-arc mantle by slab meltperidotite interaction: Evidence from mantle xenoliths in the north Kamchatka arc. J Petrol 36(6):1505-1527

König S, Schuth S, Münker C, Qopoto C (2007) The role of slab melting in the petrogenesis of high-Mg andesites: evidence from Simbo Volcano, Solomon Islands. Contrib Mineral Petrol 153(1):85-103

Kroenke LW (1995) A morphotectonic interpretation of SOPACMAPS 1:500 000 charts, Central Solomon Islands - Southern Tuvalu. In: SOPAC Technical Report. SOPAC, Fiji,

Le Maitre RW, Bateman P, Dudek A, Keller J, Lameyre J, Le Bas MJ, Sabine PA, Schmid R, Sorensen H, Streckeisen A, Woolley AR, Zanettin B (1989) A Classification of Igneous Rocks and Glossary of Terms: Recommendations of the International Union of Geological Sciences Subcommission on the Systematics of Igneous Rocks. Blackwell Scientific, Oxford

Mann P, Taylor FW, Lagoe MB, Quarles A, Burr G (1998) Accelerating late Quaternary uplift of the New Georgia Island Group (Solomon island arc) in response to subduction of the recently active Woodlark spreading center and Coleman seamount. Tectonophysics 295(3-4):259-306

Martin RF (2007) Amphiboles in the igneous environment. In: Amphiboles: Crystal Chemistry, Occurrence, and Health Issues, vol 67. Mineralogical Soc Amer, pp 323-357

McInnes BIA, Cameron EM (1994) Carbonated, alkaline hybridizing melts from a sub-arc environment: Mantle wedge samples from the Tabar-Lihir-Tanga-Feni arc, Papua New Guinea. Earth Planet Sci Lett 122(1-2):125141

McInnes BIA, Gregoire M, Binns RA, Herzig PM, Hannington MD (2001) Hydrous metasomatism of oceanic sub-arc mantle, Lihir, Papua New Guinea: petrology and geochemistry of fluid-metasomatised mantle wedge xenoliths. Earth Planet Sci Lett 188(1-2):169-183

Moore G, Carmichael ISE (1998) The hydrous phase equilibria (to 3 kbar) of an andesite and basaltic andesite from western Mexico: constraints on water content and conditions of phenocryst growth. Contrib Mineral Petrol 130(3-4):304-319

Pearce JA (1982) Trace element characteristics of lavas from destructive plate boundaries. In: Thorpe RS (ed) Andesites: Orogenic Andesites and Related Rocks. John Wiley and Sons, Chichester, pp 525-548

Pearce JA, Peate DW (1995) Tectonic implications of the composition of volcanic arc magmas. Annu Rev Earth Planet Sci 23:251-285

Peate DW, Pearce JA, Hawkesworth CJ, Colley H, Edwards CMH, Hirose K (1997) Geochemical variations in Vanuatu arc lavas: the role of subducted material and a variable mantle wedge composition. J Petrol 38(10):1331-1358

Perfit MR, Langmuir CH, Baekisapa M, Chappell BW, Johnson RW, Staudigel H, Taylor SR (1987) Geochemistry and petrology of volcanic rocks from the Woodlark Basin; addressing questions of ridge subduction. In: Taylor B, Exon NF (eds) Marine Geology, Geophysics and Geochemistry of the Woodlark Basin-Solomon Islands, vol 7. pp 113-154 
Petterson MG, Babbs T, Neal CR, Mahoney JJ, Saunders AD, Duncan RA, Tolia D, Magu R, Qopoto C, Mahoa H, Natogga D (1999) Geological-tectonic framework of Solomon Islands, SW Pacific; crustal accretion and growth within an intra-oceanic setting. Tectonophysics 301(1-2):35-60

Petterson MG, Cronin SJ, Taylor PW, Tolia D, Papabatu A, Toba T, Qopoto C (2003) The eruptive history and volcanic hazards of Savo, Solomon Islands. Bull Volcanol 65(2-3):165-181

Petterson MG, Neal CR, Mahoney JJ, Kroenke LW, Saunders AD, Babbs TL, Duncan RA, Tolia D, McGrail B (1997) Structure and deformation of north and central Malaita, Solomon Islands; tectonic implications for the Ontong Java Plateau-Solomon arc collision, and for the fate of oceanic plateaus. Tectonophysics 283(1-4):1-33

Phinney EJ, Mann P, Coffin MF, Shipley TH (2004) Sequence stratigraphy, structural style, and age of deformation of the Malaita accretionary prism (Solomon arc-Ontong Java Plateau convergent zone). Tectonophysics 389(3-4):221-246

Rapp RP, Shimizu N, Norman MD, Applegate GS (1999) Reaction between slab-derived melts and peridotite in the mantle wedge: experimental constraints at 3.8 GPa. Chem Geol 160:335-356

Richards JP, Kerrich R (2007) Special Paper: Adakite-like rocks: their diverse origins and questionable role in metallogenesis. Econ Geol 102(4):537-576

Rohrbach A, Schuth S, Münker C, Ballhaus C (2003) Island arc picrites from the Solomon Islands - origin by mantle matrix collapse. Geophys Res Abstr 5:11716

Royse KR, Kempton PD, Darbyshire DPF (1998) Procedure for the analysis of rubidium-strontium and samarium-neodymium isotopes at the NERC Isotope Geosciences Laboratory. NERC Isotope Geosciences Laboratory Report Series No. 121

Schuth S, Rohrbach A, Münker C, Ballhaus C, Garbe-Schönberg D, Qopoto C (2004) Geochemical constraints on the petrogenesis of arc picrites and basalts, New Georgia Group, Solomon Islands. Contrib Mineral Petrol 148(3):288-304

Sisson TW, Grove TL (1993) Experimental investigations of the role of $\mathrm{H}_{2} \mathrm{O}$ in calc-alkaline differentiation and subduction zone magmatism. Contrib Mineral Petrol 113(2):143-166

Smith DJ (2008) From Slab to Sinter: The Magmatic-Hydrothermal System of Savo Volcano, Solomon Islands, Ph.D. thesis, University of Leicester

Stanton RL (1994) Ore Elements in Arc Lavas. Oxford University Press,

Taylor B (1987) A geophysical survey of the Woodlark-Solomons region. In: Taylor B, Exon NF (eds) Marine Geology, Geophysics and Geochemistry of the Woodlark Basin-Solomon Islands, vol 7. pp 25-48

Taylor B, Exon NF (1987) An investigation of ridge subduction in the Woodlark-Solomons region: introduction and overview. In: Taylor B, Exon NF (eds) Marine Geology, Geophysics and Geochemistry of the Woodlark Basin-Solomon Islands, vol 7. pp 1-24

Thirlwall MF (2002) Multicollector ICP-MS analysis of Pb isotopes using a ${ }^{207} \mathrm{~Pb}^{204} \mathrm{~Pb}$ double spike demonstrates up to 400 ppm/amu systematic errors in Tl-normalization. Chemical Geology 184(3-4):255-279

Thorkelson DJ, Breitsprecher K (2005) Partial melting of slab window margins: genesis of adakitic and nonadakitic magmas. Lithos 79(1-2):25-41

Tischendorf G, Forster HJ, Gottesmann B, Rieder M (2007) True and brittle micas: composition and solidsolution series. Mineral Mag 71:285-320

Woodhead JD, Eggins SM, Johnson RW (1998) Magma Genesis in the New Britain island arc: further insights into melting and mass transfer processes. J Petrol 39(8):1641-1668

Xiong XL, Xia B, Xu JF, Niu HC, Xiao WS (2006) Na depletion in modern adakites via melt/rock reaction within the sub-arc mantle. Chem Geol 229(4):273-292 
Tables

\begin{tabular}{|c|c|c|c|c|c|c|c|c|c|c|c|c|}
\hline $\begin{array}{l}\text { Sample } \\
\text { Location } \\
\text { Rock }\end{array}$ & $\begin{array}{c}\text { SV33 } \\
\text { Tuluka } \\
\text { MUG }\end{array}$ & $\begin{array}{c}\text { SV19 } \\
\text { Pogho. } \\
\text { MUG }\end{array}$ & $\begin{array}{c}\text { SV45 } \\
\text { Pagha. } \\
\text { MUG }\end{array}$ & $\begin{array}{c}\text { SV20 } \\
\text { Pogho. } \\
\text { MUG }\end{array}$ & $\begin{array}{c}\text { SV1 } \\
\text { Rembo. } \\
\text { MUG }\end{array}$ & $\begin{array}{c}\text { SV12 } \\
\text { Pogho. } \\
\text { BEN }\end{array}$ & $\begin{array}{c}\text { SV17 } \\
\text { Pagha. } \\
\text { TRAC }\end{array}$ & $\begin{array}{c}\text { SV44 } \\
\text { Lemboni } \\
\text { TRAC }\end{array}$ & $\begin{array}{c}\text { SV10 } \\
\text { Pogho. } \\
\text { TRAC }\end{array}$ & $\begin{array}{l}\text { SV39 } \\
\text { Crater } \\
\text { TRAC }\end{array}$ & $\begin{array}{c}\text { SV2 } \\
\text { Rembo. } \\
\text { TRAC }\end{array}$ & $\begin{array}{l}\text { SV38 } \\
\text { Crater } \\
\text { TRAC }\end{array}$ \\
\hline $\begin{array}{l}\mathrm{SiO}_{2}(\mathrm{wt} \%) \\
\mathrm{TiO}_{2}\end{array}$ & $\begin{array}{r}50.7 \\
0.86\end{array}$ & $\begin{array}{c}51.0 \\
0.72\end{array}$ & $\begin{array}{c}51.8 \\
0.63\end{array}$ & $\begin{array}{c}51.9 \\
0.75\end{array}$ & $\begin{array}{c}52.4 \\
0.68\end{array}$ & $\begin{array}{c}58.5 \\
0.52\end{array}$ & $\begin{array}{c}61.5 \\
0.42\end{array}$ & $\begin{array}{c}62.9 \\
0.44\end{array}$ & $\begin{array}{c}63.1 \\
0.37\end{array}$ & $\begin{array}{c}64.9 \\
0.33\end{array}$ & $\begin{array}{c}65.1 \\
0.25\end{array}$ & $\begin{array}{c}65.7 \\
0.33\end{array}$ \\
\hline $\mathrm{Al}_{2} \mathrm{O}_{3}$ & 16.8 & 16.5 & 16.1 & 17.4 & 15.3 & 17.6 & 18.5 & 17.9 & 18.2 & 18.2 & 17.7 & 18.4 \\
\hline $\mathrm{Fe}_{2} \mathrm{O}_{3}$ & 9.07 & 9.31 & 9.83 & 8.76 & 9.31 & 5.84 & 4.11 & 3.67 & 3.37 & 2.85 & 2.36 & 2.83 \\
\hline $\mathrm{MnO}$ & 0.16 & 0.14 & 0.12 & 0.13 & 0.15 & 0.13 & 0.10 & 0.09 & 0.10 & 0.07 & 0.06 & 0.07 \\
\hline $\mathrm{MgO}$ & 4.54 & 4.78 & 4.41 & 3.68 & 6.88 & 1.93 & 1.48 & 1.81 & 1.26 & 1.19 & 0.87 & 1.16 \\
\hline $\mathrm{CaO}$ & 9.04 & 10.0 & 9.95 & 8.00 & 10.2 & 6.48 & 4.16 & 3.68 & 4.31 & 3.07 & 2.41 & 2.98 \\
\hline $\mathrm{Na}_{2} \mathrm{O}$ & 4.50 & 3.74 & 3.98 & 4.32 & 3.71 & 5.33 & 6.23 & 6.84 & 6.10 & 7.08 & 7.56 & 7.27 \\
\hline $\mathrm{K}_{2} \mathrm{O}$ & 2.02 & 1.63 & 1.34 & 1.72 & 1.35 & 1.88 & 2.27 & 2.36 & 1.99 & 2.20 & 2.35 & 2.20 \\
\hline $\mathrm{P}_{2} \mathrm{O}_{5}$ & 0.27 & 0.22 & 0.19 & 0.21 & 0.19 & 0.19 & 0.17 & 0.24 & 0.16 & 0.16 & 0.10 & 0.15 \\
\hline LOI & 2.13 & 1.09 & 1.12 & 1.99 & -0.12 & 0.57 & 0.58 & 0.30 & 0.16 & 0.32 & 0.26 & 0.35 \\
\hline Total & 100.2 & 99.2 & 99.5 & 98.9 & 100.0 & 99.1 & 99.5 & 100.2 & 99.1 & 100.4 & 99.0 & 101.5 \\
\hline $\mathrm{Ba}(\mathrm{ppm})$ & 527 & 525 & 494 & 331 & 327 & 425 & 737 & 854 & 733 & 893 & 931 & 889 \\
\hline Co & 34 & 27 & 27 & 24 & 35 & 15 & 9 & 15 & 7 & 12 & bdl & 9 \\
\hline $\mathrm{Cr}$ & 77 & 98 & 92 & 10 & 214 & 29 & bdl & 7 & 15 & 7 & bdl & bdl \\
\hline $\mathrm{Cu}$ & 105 & 88 & 110 & 77 & 103 & 8 & 9 & 21 & 21 & 11 & bdl & 10 \\
\hline $\mathrm{Ga}$ & 20 & 20 & 24 & 21 & 19 & 22 & 25 & 25 & 26 & 24 & 22 & 24 \\
\hline $\mathrm{Nb}$ & bdl & bdl & 2 & bdl & bdl & 2 & 4 & 2 & 4 & 4 & 4 & 4 \\
\hline $\mathrm{Ni}$ & 22 & 24 & 7 & 9 & 43 & bdl & bdl & bdl & bdl & bdl & bdl & bdl \\
\hline $\mathrm{Pb}$ & bdl & bdl & 11 & bdl & bdl & bdl & bdl & 17 & 13 & 15 & 12 & 14 \\
\hline $\mathrm{Rb}$ & 23 & 22 & 34 & 26 & 21 & 31 & 40 & 42 & 45 & 47 & 49 & 44 \\
\hline Sc & 39 & 32 & 44 & 30 & 28 & 13 & bdl & bdl & bdl & bdl & bdl & bdl \\
\hline $\mathrm{Sr}$ & 849 & 849 & 1215 & 762 & 709 & 863 & 1506 & 1630 & 1427 & 1497 & 1206 & 1420 \\
\hline Th & 6 & 7 & 4 & 5 & 6 & bdl & 5 & 10 & 6 & 7 & 6 & 8 \\
\hline V & 438 & 460 & 305 & 273 & 225 & 183 & 83 & 83 & 62 & 55 & 46 & 53 \\
\hline$Y$ & 16 & 20 & 20 & 17 & 19 & 16 & 10 & 11 & 12 & 8 & 7 & 8 \\
\hline $\mathrm{Zn}$ & 85 & 89 & 55 & 64 & 61 & 46 & 47 & 45 & 47 & 38 & 31 & 38 \\
\hline $\mathrm{Zr}$ & 61 & 68 & 77 & 79 & 63 & 102 & 136 & 135 & 136 & 124 & 127 & 124 \\
\hline $\mathrm{La}$ & 11 & 11 & 11 & 8 & 8 & 10 & 11 & 14 & 10 & 9 & 6 & 10 \\
\hline $\mathrm{Ce}$ & 23 & 23 & 22 & 17 & 16 & 20 & 21 & 28 & 19 & 17 & 11 & 19 \\
\hline $\mathrm{Pr}$ & 3.1 & 2.9 & 2.8 & 2.4 & 2.2 & 2.6 & 2.6 & 3.3 & 2.4 & 2.1 & 1.3 & 2.4 \\
\hline $\mathrm{Nd}$ & 15 & 13 & 12 & 11 & 11 & 11 & 11 & 13 & 10 & 9 & 6 & 10 \\
\hline $\mathrm{Sm}$ & 3.4 & 3.1 & 2.8 & 2.7 & 2.4 & 2.3 & 2.0 & 2.5 & 2.1 & 1.3 & 1.0 & 1.7 \\
\hline Eu & 1.0 & 1.0 & 0.9 & 1.0 & 0.8 & 0.8 & 0.7 & 0.7 & 0.7 & 0.5 & 0.4 & 0.5 \\
\hline $\mathrm{Gd}$ & 3 & 3 & 3 & 3 & 2 & 2 & 2 & 2 & 2 & 1 & 1 & 1 \\
\hline $\mathrm{Tb}$ & 0.45 & 0.45 & 0.41 & 0.46 & 0.40 & 0.39 & 0.25 & 0.25 & 0.28 & 0.17 & 0.13 & 0.19 \\
\hline Dy & 2.8 & 2.7 & 2.6 & 2.8 & 2.4 & 2.2 & 1.6 & 1.5 & 1.5 & 1.0 & 0.8 & 1.2 \\
\hline Ho & 0.56 & 0.58 & 0.55 & 0.62 & 0.53 & 0.51 & 0.33 & 0.27 & 0.30 & 0.19 & 0.19 & 0.25 \\
\hline $\mathrm{Er}$ & 1.6 & 1.9 & 1.7 & 1.7 & 1.4 & 1.4 & 0.9 & 0.9 & 0.9 & 0.7 & 0.5 & 0.7 \\
\hline $\mathrm{Tm}$ & 0.22 & 0.26 & 0.20 & 0.26 & 0.21 & 0.20 & 0.14 & 0.12 & 0.15 & 0.09 & 0.08 & 0.11 \\
\hline $\mathrm{Yb}$ & 1.9 & 1.7 & 1.5 & 1.7 & 1.4 & 1.5 & 1.0 & 0.9 & 1.1 & 0.6 & 0.6 & 0.8 \\
\hline Lu & 0.24 & 0.24 & 0.20 & 0.27 & 0.20 & 0.22 & 0.16 & 0.13 & 0.17 & 0.11 & 0.10 & 0.12 \\
\hline${ }^{87} \mathrm{Sr} /{ }^{86} \mathrm{Sr}$ & 0.70412 & 0.70405 & 0.70402 & 0.70403 & 0.70400 & 0.70413 & 0.70421 & 0.70414 & 0.70421 & 0.70417 & 0.70444 & 0.70418 \\
\hline${ }^{87} \mathrm{Sr} /{ }^{86} \mathrm{Sr} \mathrm{N}$ & 0.70410 & 0.70404 & 0.70401 & 0.70402 & 0.70399 & 0.70412 & 0.70420 & 0.70413 & 0.70420 & 0.70416 & 0.70443 & 0.70417 \\
\hline${ }^{143} \mathrm{Nd} /{ }^{144} \mathrm{Nd}$ & 0.51297 & 0.51294 & 0.51296 & 0.51298 & 0.51297 & 0.51297 & 0.51296 & & 0.51296 & 0.51295 & 0.51298 & 0.51297 \\
\hline${ }^{206} \mathrm{~Pb} /{ }^{204} \mathrm{~Pb}$ & 18.449 & 18.485 & & 18.449 & 18.451 & 18.455 & 18.443 & 18.449 & 18.445 & 18.461 & & 18.461 \\
\hline${ }^{207} \mathrm{~Pb} /{ }^{204} \mathrm{~Pb}$ & 15.521 & 15.524 & & 15.520 & 15.518 & 15.521 & 15.520 & 15.520 & 15.520 & 15.521 & & 15.522 \\
\hline${ }^{208} \mathrm{~Pb} /{ }^{204} \mathrm{~Pb}$ & 38.269 & 38.317 & & 38.265 & 38.273 & 38.268 & 38.263 & 38.268 & 38.266 & 38.269 & & 38.277 \\
\hline
\end{tabular}

Table 1: Whole rock major and trace element chemistry, and radiogenic isotope composition of main suite samples. 


\begin{tabular}{|c|c|c|c|c|c|c|c|c|c|c|c|}
\hline \multirow{2}{*}{$\begin{array}{l}\text { Sample } \\
\text { Location } \\
\text { Rock }\end{array}$} & \multicolumn{2}{|c|}{ Standards } & \multirow{2}{*}{$\begin{array}{l}\text { SV159 } \\
\text { Soulo. } \\
\text { CPXITE }\end{array}$} & \multirow{2}{*}{$\begin{array}{c}\text { SV161 } \\
\text { Soulo. } \\
\text { CPXITE }\end{array}$} & \multirow{2}{*}{$\begin{array}{l}\text { SV181 } \\
\text { Soulo. } \\
\text { HBLITE }\end{array}$} & \multirow{2}{*}{$\begin{array}{l}\text { SV155 } \\
\text { Soulo. } \\
\text { HBLITE }\end{array}$} & \multirow{2}{*}{$\begin{array}{l}\text { SV175 } \\
\text { Soulo. } \\
\text { HBLITE }\end{array}$} & \multirow{2}{*}{$\begin{array}{c}\text { SV6A } \\
\text { Pogholav. } \\
\text { HBLITE }\end{array}$} & \multirow{2}{*}{$\begin{array}{c}\text { SV59 } \\
\text { Mbonala } \\
\text { GAB }\end{array}$} & \multirow{2}{*}{$\begin{array}{c}\text { SV350 } \\
\text { Kalaka } \\
\text { GAB }\end{array}$} & \multirow{2}{*}{$\begin{array}{c}\text { SV365 } \\
\text { Tuluka } \\
\text { GAB }\end{array}$} \\
\hline & Average & $1 \sigma$ & & & & & & & & & \\
\hline $\begin{array}{l}\mathrm{SiO}_{2}(\mathrm{wt} \%) \\
\mathrm{TiO}_{2}\end{array}$ & $\begin{array}{c}39.4^{1} \\
3.84\end{array}$ & $\begin{array}{l}0.32 \\
0.12\end{array}$ & $\begin{array}{c}44.4 \\
0.31\end{array}$ & $\begin{array}{c}49.8 \\
0.31\end{array}$ & $\begin{array}{c}34.1 \\
1.61\end{array}$ & $\begin{array}{c}42.0 \\
1.07\end{array}$ & $\begin{array}{c}42.8 \\
0.91\end{array}$ & $\begin{array}{c}43.4 \\
0.52\end{array}$ & $\begin{array}{c}40.6 \\
1.22\end{array}$ & $\begin{array}{c}43.8 \\
1.18\end{array}$ & $\begin{array}{l}49.7 \\
0.79\end{array}$ \\
\hline $\mathrm{Al}_{2} \mathrm{O}_{3}$ & 8.52 & 0.16 & 3.5 & 3.0 & 13.4 & 11.3 & 10.8 & 12.2 & 18.6 & 18.2 & 17.4 \\
\hline $\mathrm{Fe}_{2} \mathrm{O}_{3}$ & 18.1 & 0.11 & 13.2 & 8.47 & 22.7 & 13.7 & 13.4 & 12.5 & 14.1 & 13.5 & 8.73 \\
\hline $\mathrm{MnO}$ & 0.16 & 0.01 & 0.21 & 0.12 & 0.23 & 0.12 & 0.12 & 0.22 & 0.18 & 0.12 & 0.17 \\
\hline $\mathrm{MgO}$ & 13.9 & 0.12 & 26.3 & 19.7 & 7.92 & 14.4 & 14.8 & 14.2 & 6.26 & 6.59 & 3.10 \\
\hline $\mathrm{CaO}$ & 14.9 & 0.24 & 10.1 & 19.1 & 13.9 & 13.6 & 13.6 & 12.9 & 13.2 & 12.5 & 9.66 \\
\hline $\mathrm{Na}_{2} \mathrm{O}$ & 0.79 & 0.02 & 0.90 & 0.29 & 2.56 & 2.25 & 2.22 & 2.34 & 2.50 & 2.51 & 3.92 \\
\hline $\mathrm{K}_{2} \mathrm{O}$ & 0.20 & 0.02 & 0.17 & 0.03 & 0.68 & 0.54 & 0.58 & 0.46 & 0.44 & 0.56 & 1.77 \\
\hline $\mathrm{P}_{2} \mathrm{O}_{5}$ & 0.06 & 0.01 & 0.01 & & 1.34 & 0.01 & 0.00 & 0.01 & 1.13 & 0.08 & 0.25 \\
\hline LOI & & & 1.43 & -0.09 & 0.47 & 0.22 & 0.28 & 0.30 & 0.74 & 0.35 & 3.80 \\
\hline Total & & & 100.5 & 100.7 & 98.9 & 99.1 & 99.6 & 98.9 & 99.0 & 99.5 & 99.6 \\
\hline $\mathrm{Ba}(\mathrm{ppm})$ & 58 & 8 & 26 & 9 & 107 & 61 & 67 & 33 & 97 & 139 & 383 \\
\hline Co & 84 & 2 & 103 & 55 & 39 & 60 & 63 & 52 & 38 & 43 & 25 \\
\hline $\mathrm{Cr}$ & 527 & 25 & 1236 & 1871 & 40 & 249 & 345 & 731 & 28 & & 11 \\
\hline $\mathrm{Cu}$ & 138 & 5 & & & 109 & & 81 & 8 & 225 & 102 & 87 \\
\hline $\mathrm{Ga}$ & 18 & 1 & 6 & 5 & 21 & 15 & 12 & 17 & 23 & 23 & 22 \\
\hline $\mathrm{Nb}$ & 20 & 1 & & & & & & 2 & 2 & & 2 \\
\hline $\mathrm{Ni}$ & 198 & 7 & 414 & 163 & 7 & 89 & 86 & 183 & & & 7 \\
\hline $\mathrm{Pb}$ & 5 & 2 & & & & & & & & & \\
\hline $\mathrm{Rb}$ & 10 & 1 & 4 & 3 & 4 & 4 & 4 & 4 & 5 & 4 & 23 \\
\hline Sc & 55 & 1 & 45 & 85 & 36 & 75 & 71 & 63 & 32 & 45 & 29 \\
\hline $\mathrm{Sr}$ & 269 & 2 & 112 & 52 & 463 & 261 & 193 & 179 & 674 & 667 & 921 \\
\hline Th & 2 & 2 & & & & & & 5 & 5 & & \\
\hline V & 552 & 20 & 130 & 185 & 459 & 572 & 503 & 214 & 430 & 444 & 266 \\
\hline$Y$ & 15 & 2 & 6 & 6 & 26 & 13 & 11 & 17 & 24 & 15 & 19 \\
\hline $\mathrm{Zn}$ & 207 & 7 & 76 & 33 & 97 & 52 & 41 & 98 & 74 & 70 & 67 \\
\hline $\mathrm{Zr}$ & 110 & 4 & 10 & 6 & 31 & 16 & 10 & 19 & 34 & 30 & 73 \\
\hline $\mathrm{La}$ & $5^{2}$ & 0 & & & 6 & & & 1 & & & \\
\hline $\mathrm{Ce}$ & 13 & 0 & & & 14 & & & 4 & & & \\
\hline $\mathrm{Pr}$ & 2.0 & 0.0 & & & 2.7 & & & 1.0 & & & \\
\hline $\mathrm{Nd}$ & 10 & 0 & & & 16 & & & 6 & & & \\
\hline $\mathrm{Sm}$ & 3.3 & 0.1 & & & 4.7 & & & 1.9 & & & \\
\hline $\mathrm{Eu}$ & 1.1 & 0.0 & & & 1.6 & & & 0.6 & & & \\
\hline $\mathrm{Gd}$ & 4 & 0 & & & 0.75 & & & 0.39 & & & \\
\hline $\mathrm{Tb}$ & 0.68 & 0.01 & & & 6 & & & 2 & & & \\
\hline Dy & 4.9 & 0.1 & & & 4.7 & & & 2.3 & & & \\
\hline Ho & 1.01 & 0.02 & & & 0.96 & & & 0.51 & & & \\
\hline Er & 3.1 & 0.1 & & & 2.8 & & & 1.4 & & & \\
\hline Tm & 0.43 & 0.01 & & & 0.37 & & & 0.20 & & & \\
\hline $\mathrm{Yb}$ & 3.0 & 0.2 & & & 2.4 & & & 1.2 & & & \\
\hline $\mathrm{Lu}$ & 0.43 & 0.01 & & & 0.32 & & & 0.24 & & & \\
\hline${ }^{87} \mathrm{Sr} /{ }^{86} \mathrm{Sr}$ & $0.704110^{3}$ & 0.000005 & & & & & & 0.70420 & & & \\
\hline${ }^{87} \mathrm{Sr} /{ }^{86} \mathrm{Sr} \mathrm{N}$ & 0.704097 & & & & & & & 0.70418 & & & \\
\hline${ }^{143} \mathrm{Nd} /{ }^{144} \mathrm{Nd}$ & $0.511104^{4}$ & 0.000006 & & & & & & & & & \\
\hline${ }^{206} \mathrm{~Pb} /{ }^{204} \mathrm{~Pb}$ & $18.380^{5}$ & 0.001 & & & & & & & & & \\
\hline${ }^{207} \mathrm{~Pb} /{ }^{204} \mathrm{~Pb}$ & 15.563 & 0.001 & & & & & & & & & \\
\hline${ }^{208} \mathrm{~Pb} /{ }^{204} \mathrm{~Pb}$ & 38.697 & 0.004 & & & & & & & & & \\
\hline
\end{tabular}

Table 2: Whole rock major and trace element chemistry, and radiogenic isotope composition of nodules. Also includes data (average values and one standard deviation) of reference materials analysed along with samples from Savo. 




Fig. 1: Map of the Solomon Islands showing major tectonic features, and locations discussed in the text.

Woodlark seafloor ages from Taylor (1987). Plate motions from Petterson et al. (1999).

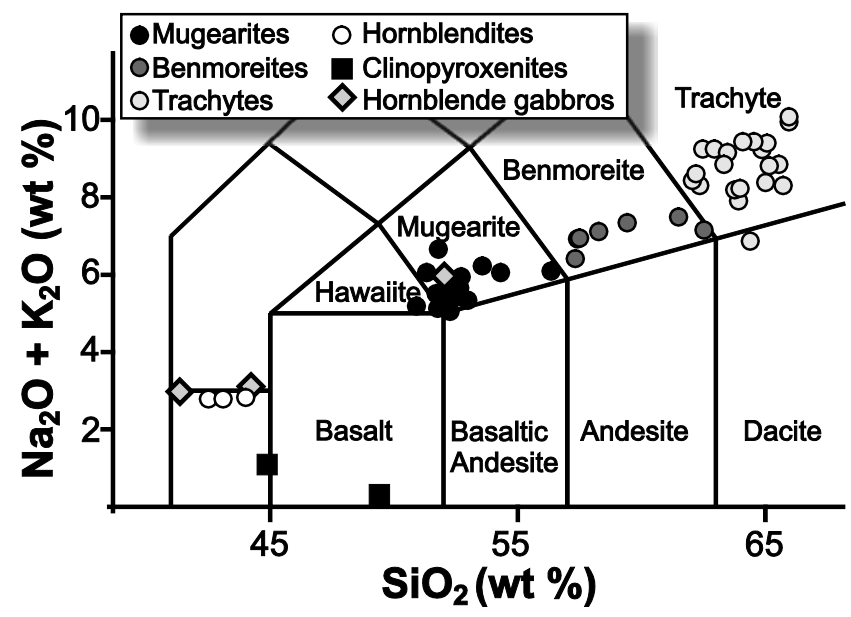

Fig. 2: Total alkalis vs. silica for samples from Savo (after Le Maitre et al. 1989). Samples recalculated to $100 \%$ on a volatile-free basis. Samples are sodic $\left(\mathrm{Na}_{2} \mathrm{O}-2>\mathrm{K}_{2} \mathrm{O}\right)$, contain less than $20 \%$ normative quartz, and are thus classified as a hawaiite-trachyte series. 



Fig. 3: Thin section photomicrographs samples from Savo: A) typical crystal-rich trachyte (SV10) in cross polarised light; B) crystalline olivine-clinopyroxene mugearite (SV1); C) benmoreite with fresh clinopyroxene, and amphibole replaced by a mixture of clinopyroxene + magnetite + plagioclase (SV12); D) hornblendite with clinopyroxene (SV175); E) hornblendite with intercumulus plagioclase and apatite in trachyte host rock (SV181); F) hornblende gabbro with hornblende, clinopyroxene and plagioclase (SV55). 


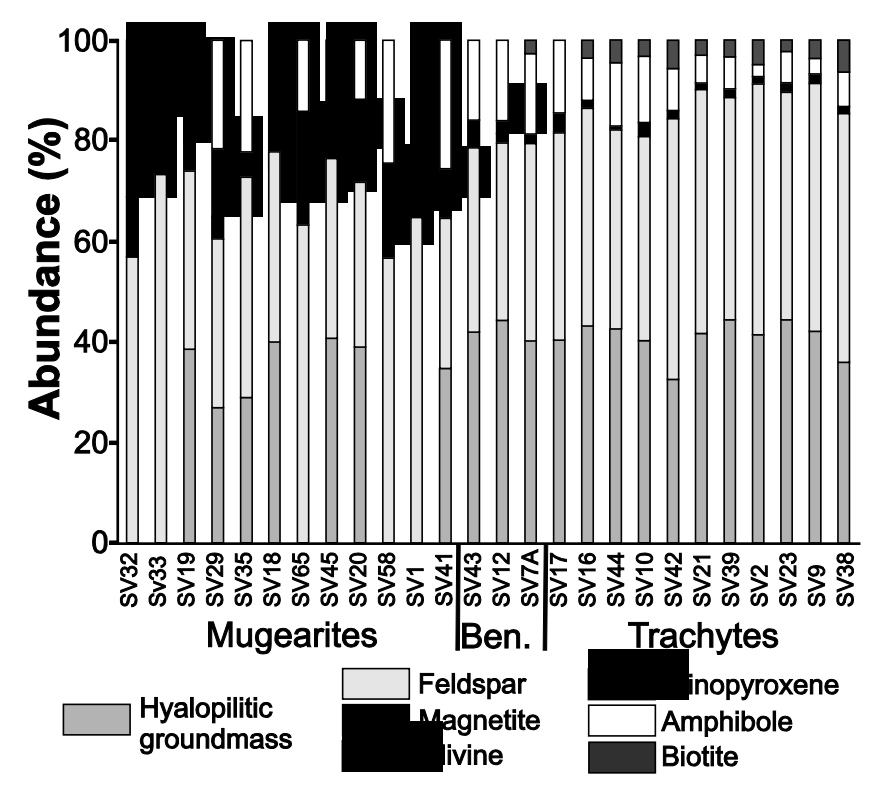

Fig. 4: Modal mineralogy of main suite thin sections as determined by point counting (minimum 750 points). Samples are ordered by increasing $\mathrm{SiO}_{2}$ contents, left to right.

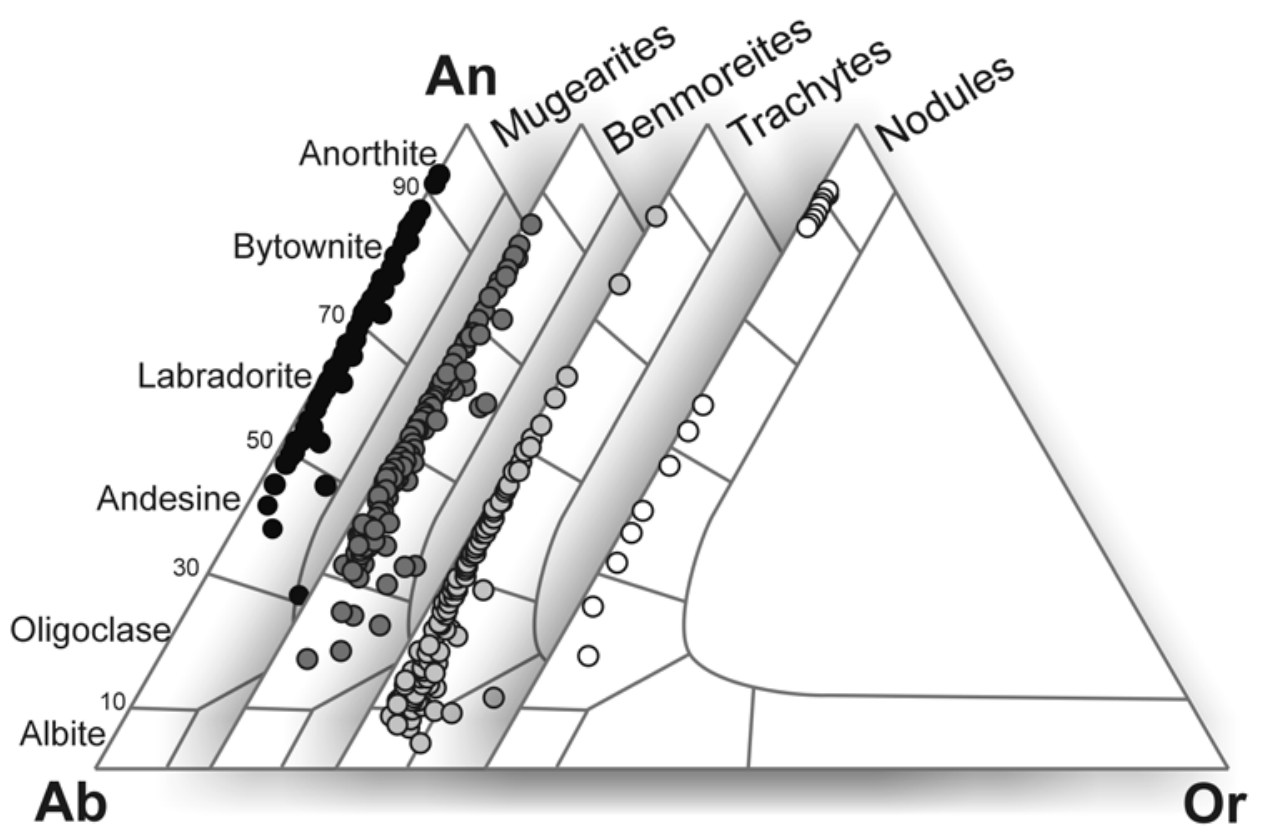

Fig. 5: Plagioclase compositions from unaltered samples. 


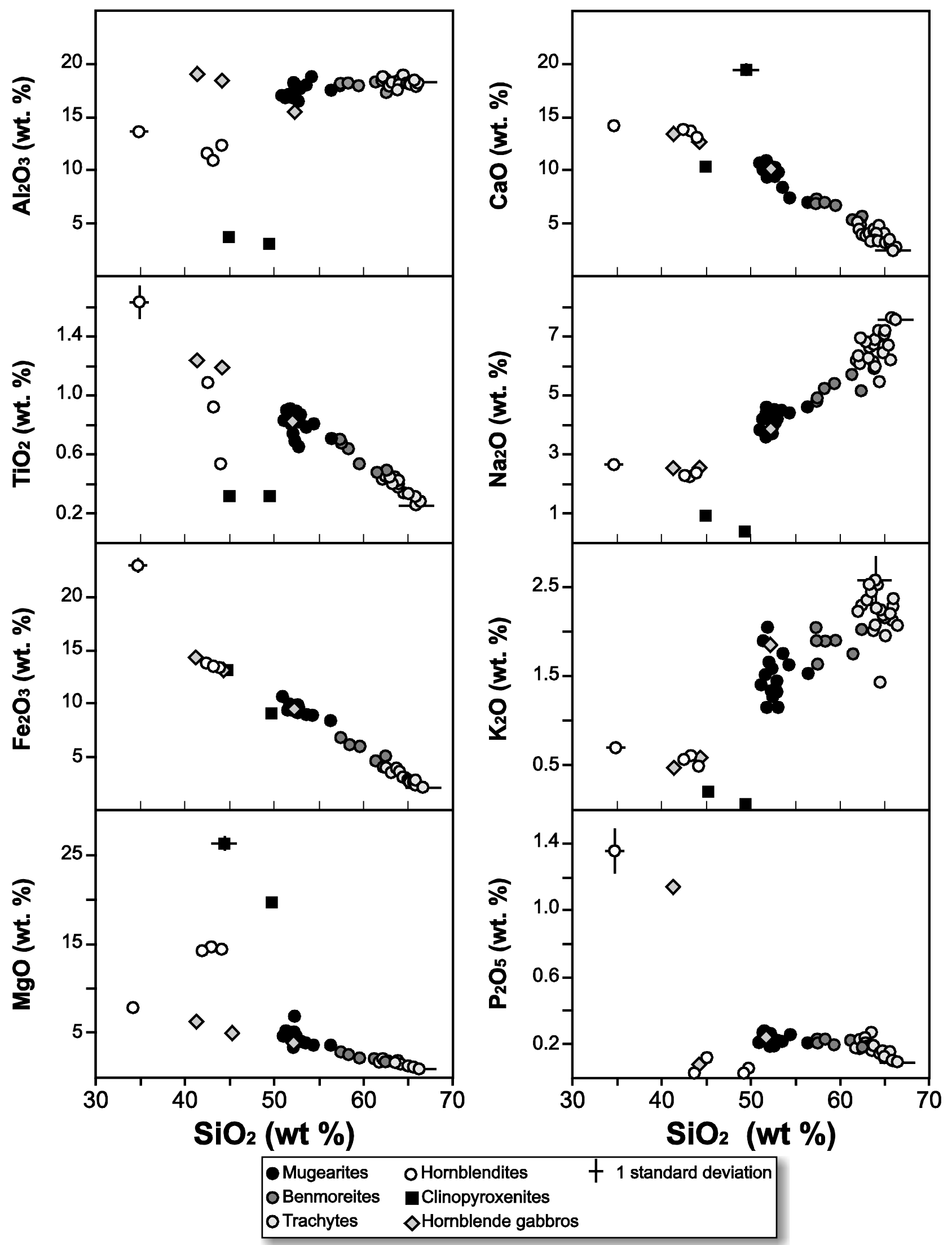

Fig. 6: Major element Harker variation diagrams for main suite samples and nodules from Savo Island. All data recalculated to $100 \%$ on a volatile-free basis. Also shows results of least-squares fractionation models discussed in text. Error bars show typical precision (1 standard deviation). 

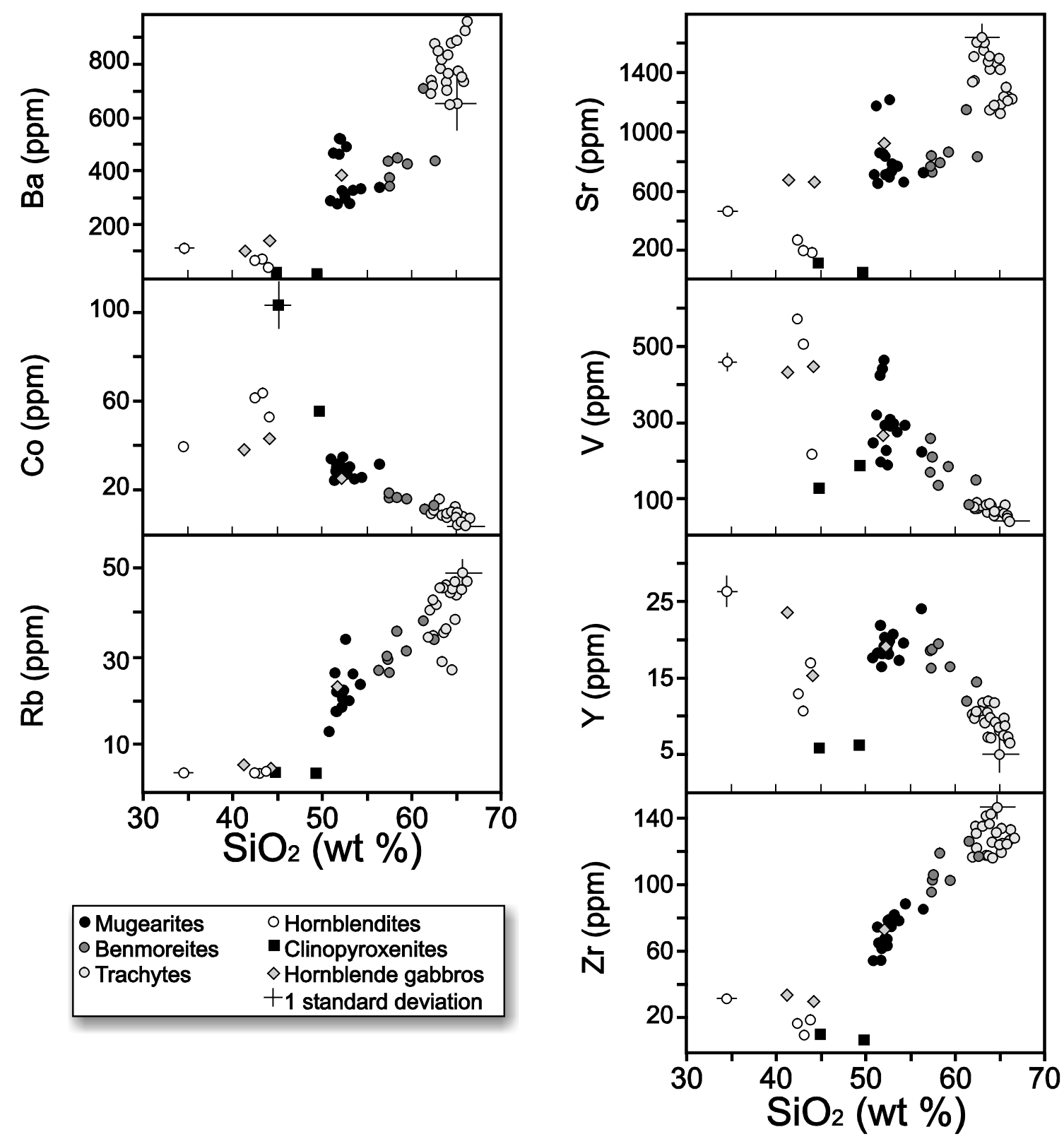

Fig. 7: Selected trace element Harker variation diagrams for main suite and nodule samples from Savo Island. $\mathrm{SiO}_{2}$ from major element analyses, recalculated to $100 \%$ on a volatile-free basis. Error bars show typical precision (1 standard deviation). 


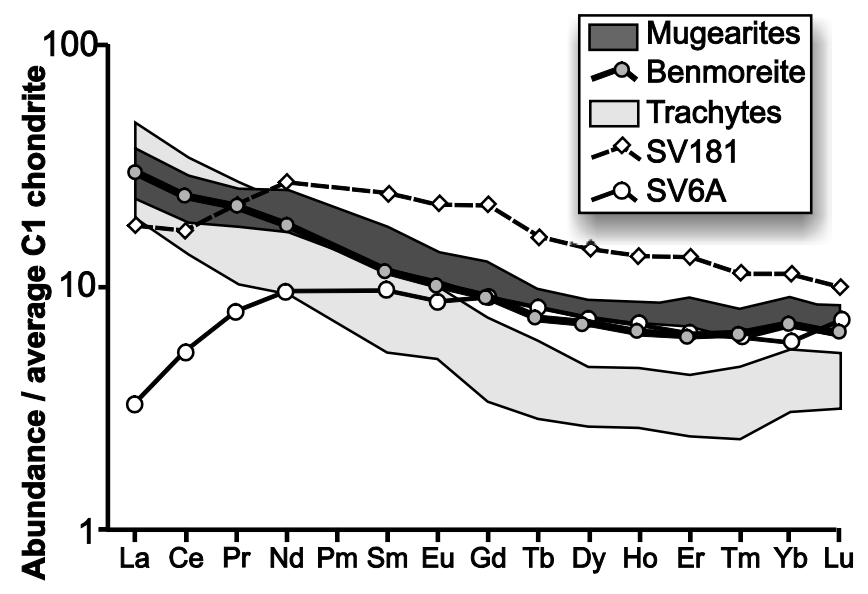

Fig. 8: Chondrite-normalised REE plot for a subset of samples from Savo. Normalising values from Boynton (1984). Hornblendite sample SV181 has a significant quantity of apatite $\left(\mathrm{P}_{2} \mathrm{O}_{5}>1 \mathrm{wt} \%\right)$ and is LREE-enriched relative to hornblendite SV6A. 

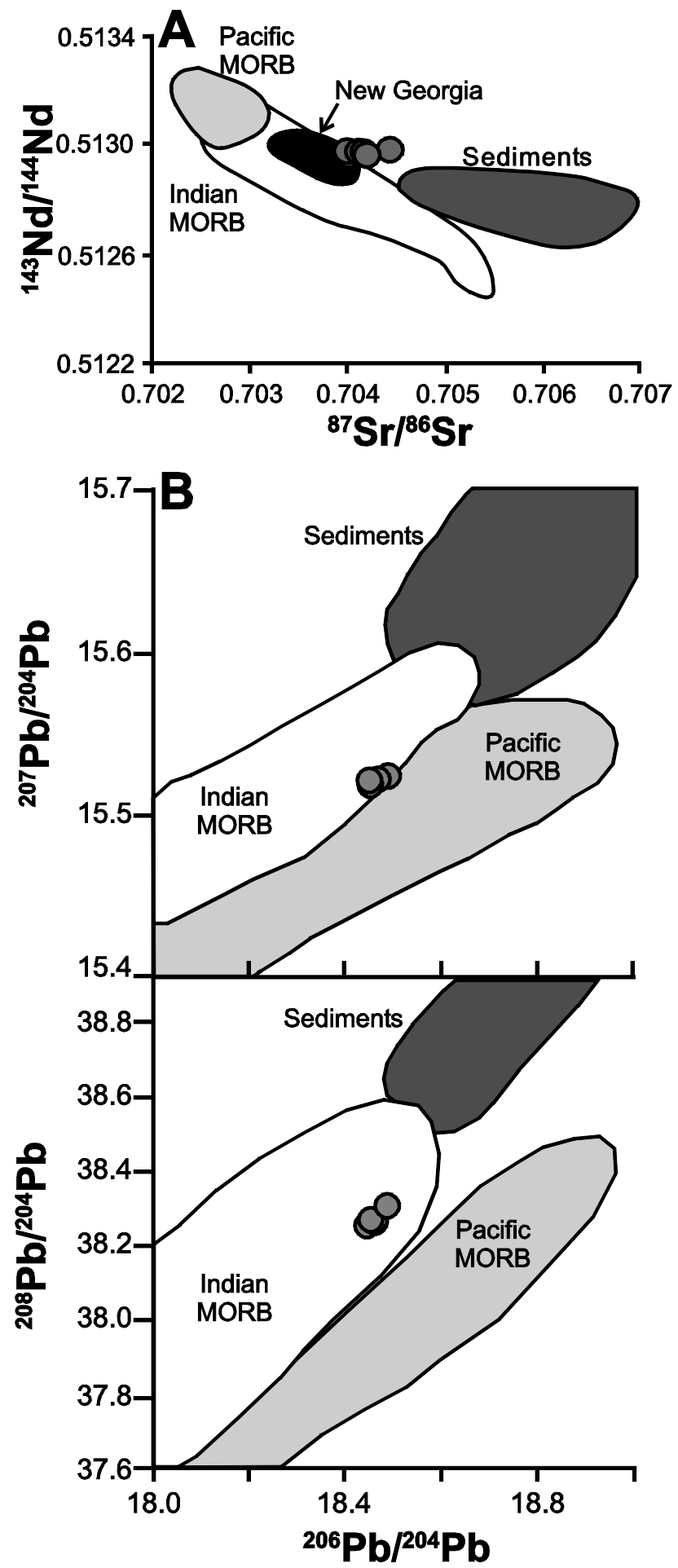

Fig. 9: A) Sr-Nd diagram for samples from Savo. Fields for Pacific and Indo-Australian MORB from Hofmann (1997), New Georgia field from Schuth et al. (2004), and sediments field from König et al. (2007). Error within point size. B) Whole rock common lead isotopes for Savo. Fields from Peate et al. (1997). Error within point size. 


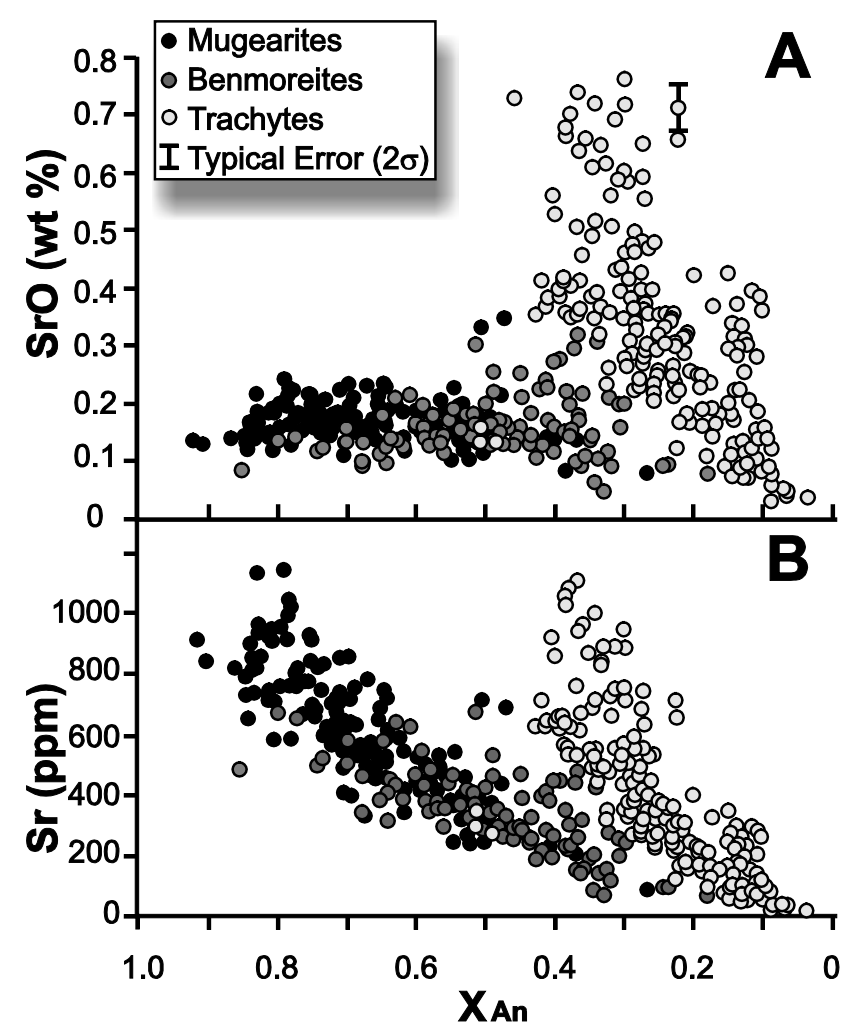

Fig. 10: A) Behaviour of SrO (wt \%) with decreasing $X_{\text {An }}$ (mole fraction anorthite) in plagioclase for a subset of electron microprobe analyses (includes core-to-rim analysis of zones crystals). Points are shaded according to host rock composition. B) Equilibrium melt $S r(p p m)$ contents, based on $D_{S r}$ values calculated for a given $X_{A n}$ from the equation of Blundy and Wood (1991).



Fig. 11: Behaviour of $\mathrm{BaO}(\mathrm{wt} \%)$ with decreasing $\mathrm{X}_{\mathrm{An}}$ in plagioclase for a subset of electron microprobe analyses (includes core-to-rim analysis of zoned crystals. Points are shaded according to host rock comparison. Analytical precision is too low to resolve significant variations in calculated equilibrium melt compositions (not shown). 




